\title{
Effect Of Processing Conditions On Phytochemical Constituents Of Edible Irish Seaweed Himanthalia Elongata.
}

\author{
Sabrina Cox \\ Technological University Dublin, sabrina.cox@tudublin.ie \\ Nissreen Abu-Ghannam \\ Technological University Dublin, nissreen.abughannam@tudublin.ie \\ Shilpi Gupta \\ Technological University Dublin, shilpi.19may@gmail.com
}

Follow this and additional works at: https://arrow.tudublin.ie/schfsehart

Part of the Food Chemistry Commons, Food Microbiology Commons, and the Food Processing Commons

\section{Recommended Citation \\ Cox, S., Abu-Ghannam, N., Gupta, S. (2011). Effect Of Processing Conditions On Phytochemical Constituents Of Edible Irish Seaweed Himanthalia Elongata. Journal of Food Processing and Preservation, 36 (4), pp.348-363. doi:10.1111/j.1745-4549.2011.00563.x}

This Article is brought to you for free and open access by the School of Food Science and Environmental Health at ARROW@TU Dublin. It has been accepted for inclusion in Articles by an authorized administrator of ARROW@TU Dublin. For more information, please contact arrow.admin@tudublin.ie, aisling.coyne@tudublin.ie, gerard.connolly@tudublin.ie. Funder: ABBEST

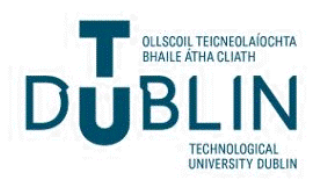


1 Effect of processing conditions on phytochemical constituents of edible Irish seaweed

6

7

8

9

10

11

12

13

14

15

16

17

18

19

20

21

22

23

24 *Corresponding author: Dr. Nissreen Abu-Ghannam

25 Tel: +35314027570; Email: nissreen.abughannam@dit.ie

\section{Himanthalia elongata}

Sabrina Cox, Nissreen Abu-Ghannam* and Shilpi Gupta

Journal of Food Processing and Preservation.

Accepted: 25/04/11

School of Food Science and Environmental Health,

Dublin Institute of Technology, Cathal Brugha St.,

Dublin 1, Ireland. 


\section{Abstract}

Seaweed is well recognised as an excellent source of phytochemicals. This study was a preliminary screening to investigate the effects of various food processing methods on the phytochemicals of Himanthalia elongata. Hydrothermal processing was carried out until an edible texture was achieved. The total phenolic content (TPC) of fresh H. elongata was $175.27 \mathrm{mg} \mathrm{GAE} / 100 \mathrm{~g}$ fresh weight (FW) while boiling significantly reduced the TPC to 25.4 mg GAE/100 g FW ( $\mathrm{p}<0.05)$. A drying pre-treatment before boiling reduced the cooking time therefore leading to less leaching of antioxidants upon boiling. In terms of extract, drying of $H$. elongata followed by boiling had the most significant effect on the phytochemicals as TPC increased by $174 \%$. Boiled extracts had the most effective DPPH scavenging activity $\left(\mathrm{EC}_{50}\right.$ of $\left.12.5 \mu \mathrm{g} / \mathrm{ml}\right)$. As a comparison, seaweed subjected to the same treatments were studied in terms of antimicrobial activity. Overall, extracts from fresh $H$. elongata achieved the highest inhibition.

Keywords: Seaweed, Himanthalia elongata, processing, antioxidants, antimicrobials.

\section{Introduction}

In recent years, many marine resources have attracted attention in the search for bioactive compounds to develop new drugs and health foods (Kuda et al., 2005). Seaweeds are a known source of bioactive compounds as they are able to produce a great variety of secondary metabolites characterized by a broad spectrum of biological activities (Bansemir et $a l .$, 2006). Compounds with antiviral, antifungal, antimicrobial and antioxidant activities have been detected in green, brown and red algae (Vairappan et al., 2001; Bansemir et al., 2006; Duan et al., 2006; Chandini et al., 2008; Cox et al., 2010). Antioxidant activity of marine algae may arise from pigments such as chlorophylls and carotenoids, vitamins and vitamin precursors including a-tocopherol, $\beta$-carotene, niacin, thiamine and ascorbic acid, phenolics such as polyphenolics and hydroquinones and flavonoids, phospholipids particularly phosphatidylcholine, terpenoids, peptides, and other antioxidative substances, which directly or indirectly contribute to the inhibition or suppression of oxidation processes (Shahidi, 2009). The environment in which seaweeds grow is harsh as they are exposed to a 
combination of light and high oxygen concentrations. These factors can lead to the formation of free radicals and other strong oxidizing agents but seaweeds seldom suffer from any serious photodynamic damage during metabolism. This fact implies that their cells have some protective antioxidative mechanisms and compounds (Matsukawa et al., 1997).

60 Reactive oxygen species (ROS) such as hydroxyl, superoxide and peroxyl radicals are formed

61 in human cells by endogenous factors and result in extensive oxidative damage which can lead to age related degenerative conditions, cancer and a wide range of other human diseases (Reaven and Witzum, 1996; Aruoma, 1999). Phenolic compounds can act as antioxidants by chelating metal ions, preventing radical formation and improving the antioxidant endogenous system (Al-Azzawie and Mohamed-Saiel, 2006). These phenolic compounds are commonly found in plants, including seaweeds (Duan et al., 2006). Polyphenols represent a diverse class of compounds including flavonoids (i.e. flavones, flavonols, flavanones, flavononols, chalcones and flavan-3-ols), lignins, tocopherols, tannins and phenolic acids (Shukla et al., 1997).

Interest in new sources of natural antioxidants has increased in recent years in order to reduce the use of synthetic forms such as Butylated Hydroxyanisole (BHA) and Butylated Hydroxytoluene (BHT). Natural antioxidants from plant origin can react rapidly with these free radicals and retard or alleviate the extent of oxidative deterioration (Akoh and Min, 1997). Furthermore, antioxidants from natural sources can also increase the shelf life of foods. Phenolic phytochemicals inhibit autoxidation of unsaturated lipids, thus preventing the formation of oxidized low-density lipoprotein (LDL), which is considered to induce cardiovascular diseases (Amic et al., 2003). Therefore, the consumption of foods with high levels of these phytochemicals or addition of such extracts could protect the body as well as the foods against these events (Chandini et al., 2008). 
80 Marine algae have been consumed in Asia since ancient times, but to a much lesser extent in the rest of the world. Many plant-based foods can be eaten raw or after cooking. Cooking can be performed in various ways but, for vegetables, most common are steaming, boiling and microwaving. These cooking processes would bring about a number of changes in physical characteristics and chemical composition of the vegetables (Zhang and Hamauzu, 2004). Reports on the effects of cooking on the antioxidant compounds in vegetables have been inconclusive. There are reports demonstrating an enhancement or no change in antioxidant activity of vegetables (Gahler et al., 2003; Turkman et al., 2005) while others have indicated a deterioration of activity after thermal treatment (Ismail et al., 2004; Zhang and Hamazu, 2004).

The presence and diversity of phytochemicals in vegetables are important factors for human health. The phytochemical contents in untreated vegetables have been the most studied. Since a large part of ingested vegetables are generally thermally processed prior to consumption, it is also important to investigate how the processing affects the levels of these compounds

94 (Volden et al., 2009). Processing of vegetables for consumption exposes the phytochemicals present to detrimental factors that may lead to alterations in concentrations and health related quality. For example wet-thermal treatment causes denaturation of enzymes that can catalyse breakdown of nutrients and phytochemicals. On the other hand, processing by heat can result in reduction of constituents by leaching or due to thermal destruction (Rungapamestry et al., 2007). Turkmen et al. (2005) revealed that different cooking methods (boiling, steaming and

100 microwaving) caused losses of phenolics from squash, peas and leek. However, under similar 101 conditions, an increase in the phenolic content of vegetables such as green beans, peppers and broccoli was reported (Turkman et al., 2005). Watchtel-Galor et al. (2008) found that

103 steaming and microwaving led to losses in the total phenolic content of broccoli, choy-sum 
104 and cabbage, although steaming had significantly less loss than microwaved samples. Volden et al. (2009) also reported loss of phytochemicals in steamed cauliflower (19\%).

106 The traditional process to preserve seaweeds is by sun drying (Lim and Murtijaya, 2007) as

107 several seaweeds are perishable in their fresh state and could deteriorate within a few days

108 after harvest. Drying is one of the most common food processing methods that can be used to

109 extend the shelf-life and to achieve the desired characteristics of a food product. Reducing the

110 water activity $\left(a_{w}\right)$ of food via this process can minimize deterioration from chemical

111 reactions and microbial activity (Chiewchan et al., 2010). Dried seaweeds are rehydrated by

112 various methods such as boiling before consumption, therefore in the present study drying

113 was considered as a pre-treatment before cooking.

114 Food poisoning is a concern for both consumers and the food industry despite the use of 115 various preservation methods. Food processors, food safety regulators and regulatory 116 agencies are continuously concerned with the high and growing number of illness or 117 outbreaks caused by some pathogenic and spoilage microorganisms in foods. Recently, 118 consumers are demanding foods which are fresh, natural and minimally processed. Along 119 with this, consumers are also concerned about the safety of foods containing synthetic 120 preservatives. This has put pressure on the food industry and has fuelled research into the 121 discovery of alternative natural antimicrobials (Shan et al., 2007).

122 Being rich in phytochemicals responsible for antioxidant and antimicrobial activity, there 123 have been many studies conducted on seaweeds to quantify these compounds (Duan et al., 124 2006; Chandini et al., 2008 and Cox et al., 2010), however little information is available on 125 the effect of hydrothermal treatment on these phytochemicals in seaweeds. The purpose of 126 this study was a preliminary screening to investigate the effect of different processing 127 methods on the phytochemical constituents present in an Irish edible brown seaweed, 128 Himanthalia elongata. The effect was studied in terms of both the extract of $H$. elongata and 
129 as a whole food. The aim was on one hand, to study the effect of common cooking treatments

130 on the phytochemicals of the brown seaweed. At the same time, the effect of drying as a pre-

131 treatment on the cooking time and phytochemical content was also assessed. Moreover, the

132 antimicrobial properties of $H$. elongata extracts against common food pathogenic and food

133 spoilage bacteria was also investigated after varied processing treatments.

\section{Methods}

2.1 Chemicals

2, 2-Diphenyl-1-picrylhydrazyl (DPPH), ascorbic acid, Folin-Ciocalteu's phenol reagent,

138 gallic acid, sodium carbonate $\left(\mathrm{Na}_{2} \mathrm{CO}_{3}\right)$, sodium benzoate, vanillin, hydrochloric acid $(\mathrm{HCl})$,

139 (+)-catecin, aluminium chloride $\left(\mathrm{AlCl}_{3}\right)$ and quercetin were purchased from Sigma Aldrich

140 Chemie (Steinheim, Germany). Tryptic Soy Broth (TSB) was purchased from Sparks

141 (Dublin, Ireland).

$143 \quad 2.2$ Seaweed material

144 H. elongata (Phaeophyta) was purchased from Quality Sea Veg., Co Donegal, Ireland. 145 Samples were collected in September and November 2009, washed thoroughly with 146 freshwater to remove epiphytes and stored at $4{ }^{\circ} \mathrm{C}$ until analysis.

$148 \quad 2.3$ Preparation of samples

149 H. elongata was washed thoroughly with tap water, dried with absorbent paper and then cut

150 into $3 \mathrm{~cm}$ long pieces before processing. The effect of processing on $H$. elongata in terms of 151 antioxidant and antimicrobial activity was evaluated by drying, boiling, steaming, 152 microwaving, and combinations of drying as a pre-treatment before boiling and steaming 153 until an edible texture was achieved as described in section 2.4. 
$154 \quad 2.4$ Determination of cooking time and texture evaluation

155 Cooking time of seaweed was selected from preliminary experiments and was determined by

156 the tactile method. To overcome the subjectivity of the tactile method, a combination of 157 tactile and instrumental textural methods were used in order to decide the cooking time of 158 seaweed. Edible texture was determined by a sensory panel consisting of 6 judges. At 5 min 159 cooking time intervals, seaweed samples were removed to undergo tactile and instrumental 160 texture analysis. Shear tests were performed using an Instron Universal Testing Machine 161 (Model 4301, Canton MA, USA) attached to Bluehill 2 version 2.14 analysis software for 162 materials testing. A Warner Bratzler cutter was used in the shear tests. An aluminium plate 163 with dimensions of $10 \times 6 \mathrm{~cm}^{2}$, thickness $1.3 \mathrm{~cm}$ with an opening of $3 \mathrm{~mm}$ in the centre was 164 supported in the Instron base. Seaweed samples (5 g) were sheared at a speed of 200 $\mathrm{mm} / \mathrm{min}$. The cutting implement was allowed to travel the depth of the seaweed, cutting through the sample and seaweed hardness was defined as the peak of force-deformation curve recorded in Newtons per $\mathrm{mm}(\mathrm{N} / \mathrm{mm})$. Ten replications of each sample were carried out.

\subsubsection{Drying pre-treatment}

170 Seaweed samples were placed in $5 \mathrm{~g}$ lots on a drying tray in a single layer. Drying of seaweed was investigated in a drier (Innova 42 , Mason Technology, Ireland) at $25^{\circ} \mathrm{C}$ air drying

172 temperature over a period of $12-24$ hours. Air velocity was $2.0 \pm 0.1 \mathrm{~m} \mathrm{~s}^{-1}$ measured with

173 VWR Enviro-meter digital anemometer (VWR, Ireland).

2.5.2 Boiling

176 The seaweed samples (dried or fresh) were boiled by immersion in $2 \mathrm{~L}$ of distilled water kept 177 at the specified boiling temperatures $\left(80\right.$ and $\left.100^{\circ} \mathrm{C}\right)$ using a water bath (Lauda, Aqualine 178 AL5, Mason Technology, Ireland) until an edible texture was achieved $(30-32 \mathrm{~N} / \mathrm{mm})$ as 
179 described in section 2.4. After boiling, the cooked seaweeds were drained using a wire mesh

180 strainer and placed on ice to cool before the extraction procedure.

181

182

\subsubsection{Steaming}

183 Regular steaming was performed on dried and fresh seaweeds using an atmospheric steam

184 cooker (Kenwood, FS360, United Kingdom). The seaweed samples (5 g), were placed in the centre tray of the steam cooker, covered with the lid and steamed over $2 \mathrm{~L}$ of boiling water.

Steaming time was selected according to preliminary experiments, in which steaming time was determined when an edible texture was achieved $(30-32 \mathrm{~N} / \mathrm{mm})$ as described in section 2.4. After the steaming process, the cooked seaweeds were drained and placed on ice to cool before the extraction procedure.

\subsubsection{Microwaving}

192 Fresh seaweed samples (5 g) were placed in a pyrex bowl, covered with a plastic film to

193 prevent water loss and microwaved in a domestic microwave oven (Sharp Platinum

194 Collection, R-957, United Kingdom) at 450 and 900 watts (W) for 30 and 20 seconds (s), respectively. Cooking time was selected according to preliminary experiments, in which microwaving time was determined when an edible texture was achieved $(30-32 \mathrm{~N} / \mathrm{mm})$ as described in section 2.4. After microwaving, the seaweeds placed on ice to cool before the extraction procedure.

2.6 Extraction of phytochemicals

201 Seaweed samples after respective processing (5 g original weight) were powdered in liquid

202 nitrogen using a mortar and pestle, then extracted with $50 \mathrm{ml}$ of methanol (60\%) under 203 nitrogen atmosphere for 2 hours. Liquid nitrogen was used as it can reduce the particle size of 
204 a large amount of seaweed in a short period of time. The extraction was carried out at $40^{\circ} \mathrm{C}$ at $205100 \mathrm{rpm}$ in a shaker incubator (Innova 42, Mason Technology, Ireland) as optimised in our 206 previous work (Cox et al., 2010). Samples were filtered using Whatman Number 1 filter 207 papers (Sigma Aldrich Chemie, Steinheim, Germany) and centrifuged at 10,000 rpm for 15 $208 \min$ (Sigma 2K15, Mason Technology, Ireland). Resulting extracts were evaporated to 209 dryness using vacuum polyevaporator (Buchi Syncore Polyvap, Mason Technology, Ireland) 210 at $60^{\circ} \mathrm{C}$. A pressure gradient program was designed for evaporation of the solvents with 211 vacuum conditions of 337 and 72 mbar for methanol and water, respectively.

2132.7 Total phenolic content

214 The total phenolic content of seaweed samples (concentration $1 \mathrm{mg} / \mathrm{ml}$ of extract in water) was measured using the Folin-Ciocalteau method as reported by Taga et al. (1984). The total phenolic contents of the whole seaweeds were expressed as mg gallic acid equivalent per 100 gram fresh weight (mg GAE/100 $\mathrm{g} \mathrm{FW}$ ) and as mg GAE/g for extracts.

\subsection{DPPH radical scavenging activity}

220 Free radical scavenging activity was measured by 2, 2-Diphenyl-1-picrylhydrazyl (DPPH) according to the method of Yen and Chen (1995) with some modifications. Briefly, a $100 \mu 1$ aliquot of test sample was placed in a 96-well microtitre plate and $100 \mu \mathrm{l}$ of $0.16 \mathrm{mM} \mathrm{DPPH}$ methanolic solution was added. The mixture was shaken and incubated for $30 \mathrm{~min}$ in darkness at $25^{\circ} \mathrm{C}$. Changes in the absorbance of the samples were measured at $517 \mathrm{~nm}$ using a microplate reader (Powerwave, Biotek, VT, USA).

227 The ability to scavenge the DPPH radical was calculated using the following equation given 228 by Duan et al. (2006): 
229 Scavenging effect $(\%)=\left[1-\left(\frac{A_{\text {sample }}-A_{\text {sampleblank }}}{A_{\text {control }}}\right)\right] \times 100$

230 Where: $A_{\text {control }}$ is the absorbance of the control (DPPH solution without sample), $A_{\text {sample }}$ is the

231 absorbance of the test sample (DPPH solution plus test sample) and $A_{\text {sample blank }}$ is the 232 absorbance of the sample only (sample without any DPPH solution). DPPH results were 233 interpreted as the "efficient concentration" or $\mathrm{EC}_{50}$ value which is the concentration of 234 substrate that causes 50\% loss of the DPPH activity.

\subsection{Total flavonoid content}

237 Total flavonoid contents were determined according to the method of Zhishen et al. (1999).

238 Quercetin was used to prepare the standard curve and results were expressed as mg quercetin 239 equivalents $(\mathrm{QE}) / 100$ gram fresh weight ( $\mathrm{mg} \mathrm{QE} / 100 \mathrm{~g} \mathrm{FW}$ ) for whole seaweeds and as $\mathrm{mg}$ $240 \quad \mathrm{QE} / \mathrm{g}$ for extracts.

2.10 Total condensed tannin content

243 Total condensed tannin contents were determined according to the method of Julkunen-Titto 244 (1985). (+)-Catechin was used to prepare the standard curve and results were expressed as mg 245 catechin equivalents (CE)/100 gram fresh weight ( $\mathrm{mg} \mathrm{CE} / 100 \mathrm{~g} \mathrm{FW}$ ) for whole seaweeds and 246 as $\mathrm{mg} \mathrm{CE} / \mathrm{g}$ for extracts.

2.11 Antimicrobial activity

2.11.1 Microbial culture

250 Two species of common food pathogenic and two species of food spoilage bacteria selected 251 for this study were Listeria monocytogenes ATCC 19115, Salmonella abony NCTC 6017, 
253 (Medical Supply Company, Dublin, Ireland). All cultures were maintained at $-70^{\circ} \mathrm{C}$ in $20 \%$ 254 glycerol stocks and grown in Tryptic Soy Broth (TSB) at $37^{\circ} \mathrm{C}$; apart from $P$. aeruginosa 255 which was incubated at $30^{\circ} \mathrm{C}$ to obtain sub-cultures. Working cultures were prepared from 256 sub-cultures and grown at optimal conditions for each bacterium for 18 hours before analysis.

257 Bacterial suspensions were then prepared in saline solution $(\mathrm{NaCl} 0.85 \%$, BioMérieux, 258 France) equivalent to a McFarland standard of 0.5, using the Densimat photometer 259 (BioMérieux Inc, France) to obtain a concentration of 1 x $10^{8}$ colony forming units $260(\mathrm{CFU}) / \mathrm{ml}$. This suspension was then diluted in TSB to obtain a working concentration of $1 \mathrm{x}$ $261 \quad 10^{6} \mathrm{CFU} / \mathrm{ml}$.

$263 \quad 2.11 .2$ Antimicrobial activity assay

264 The influence of varying concentrations of extract on efficacy was assessed against $L$. monocytogenes, S. abony, E. faecalis and P. aeruginosa using 96-well microtitre plates

266 (Sarstedt Ltd., UK). Seaweed extracts after respective processing (5 g original seaweed 267 weight) were dissolved in $2.5 \mathrm{ml}$ of TSB and $200 \mu \mathrm{l}$ was added to the first row of each plate.

268 All other wells were filled with $100 \mu \mathrm{l}$ of TSB and $100 \mu \mathrm{l}$ from the first well was serial 269 diluted two-folds along each column. Finally, $100 \mu \mathrm{l}$ of bacterial suspension containing $1 \mathrm{x}$ $10^{6} \mathrm{CFU} / \mathrm{ml}$ was added to the wells. The last column was used for bacterium and media controls and sample blanks were prepared for all of the extracts. Absorbance readings were

272 then taken at 0 and 24 hours at $600 \mathrm{~nm}$ using a microplate spectrophotometer (Powerwave,

273 Biotek) with 20 seconds agitation before each optical density (OD) measurement. Analysis of growth over time was also performed on most effective extracts. OD measurements were taken every three hours for 24 hours. Sodium benzoate and sodium nitrite were used as controls. Percentage inhibition was calculated as follows: 
277 Bacterial inhibition $(\%)=\left[\left(\frac{O-E}{O}\right)\right] \times 100$

278 Where: $O$ is (OD of the Organism at $24 \mathrm{~h}-\mathrm{OD}$ of the Organism at $0 \mathrm{~h}$ ) and $E$ is (OD of the

279 Extract at $24 \mathrm{~h}-$ Blank at $24 \mathrm{~h})-(\mathrm{OD}$ of the Extract at $0 \mathrm{~h}-$ Blank at $0 \mathrm{~h})$.

280 Results were interpreted by categorising percentage inhibitions based on inhibition intensity 281 according to Dubber and Harder (2008).

282

283

2.12 Statistical analysis

284 All experiments were performed in triplicate and replicated twice. All statistical analyses 285 were carried out using STATGRAPHICS Centurion XV. Statistical differences between different processing treatments were determined using ANOVA followed by Least Significant Difference (LSD) testing. Differences were considered statistically significant when $\mathrm{p}<0.05$.

\section{Results and Discussion}

3.1 Effect of processing on total phenolic content

292 Increased intake of vegetables is generally associated with a reduced risk of cancer and 293 cardiovascular disease (Kris-Etherton et al., 2002). Processing and preparation of vegetables, 294 especially thermal treatment, which are applied prior to consumption may affect the 295 phytochemicals. Heat applications such as boiling, steaming or microwaving are common 296 practices in the processing of food products in order to render them palatable and

297 microbiologically safe. Since seaweed would need to undergo some heat treatment prior to 298 usage, it was relevant to assess the effects of heat treatment on the stability of seaweed 299 antioxidant properties. In the present study, cooking of $H$. elongata was carried out by three 300 commonly used procedures and the antioxidant properties of the cooked product were 
301 evaluated and compared with fresh. It is a well known fact that cooking time as well as 302 cooked texture, appearance and flavour are important cooking quality characteristics (Xu and 303 Chang, 2008). Firmness or softness is one of the most important criteria in determining the 304 acceptability of foods. Acceptable texture parameters are outlined in the literature for various 305 foods such as legumes (Xu and Chang, 2008) but there are no such values previously outlined

306 for seaweed. Because sensory evaluation is based on human senses which detect myriad 307 characteristics of material properties simultaneously, it is difficult to find a good correlation between orally perceived texture and instrumentally measured texture (Nishinari, 2004).

309 Therefore, in the present study the cooking time of fresh seaweed boiled at $100^{\circ} \mathrm{C}$ was 310 calculated using a tactile and instrumental texture measurement based on the length of time it 311 took the seaweed to become edible. Samples were taken every 5 minutes and edibility was 312 judged based on the hardness and chewiness of the samples until an acceptable edible texture 313 was achieved. From these methods, it was found that softening of fresh $\mathrm{H}$. elongata from 45

$314 \mathrm{~N} / \mathrm{mm}$ to $30-32 \mathrm{~N} / \mathrm{mm}$ was an acceptable edible texture as can be seen in Table 1.

315 The total phenolic content (TPC) of processed H. elongata can be seen in Fig. 1 (A). In order to achieve an edible texture, it was necessary that $H$. elongata was boiled for 40 and 35 min

317 at $80^{\circ} \mathrm{C}$ and $100^{\circ} \mathrm{C}$, respectively. This resulted in almost 82.31 and $85.5 \%$ loss in TPC, 318 respectively as compared to fresh seaweed. A reduction of TPC from 175.27 to $25.4 \mathrm{mg}$ 319 GAE/100 g FW was observed. Similar results were obtained with steaming although it was 320 not as detrimental as boiling. The seaweed was steamed for 45 min which resulted in a loss of 321 $32.06 \%$ TPC. The reason for such high reduction during boiling could be due to leaching of nutrients in water which was proved by a reduction in the amount of extract obtained also.

323 Fresh $H$. elongata had a $3.14 \%$ yield of extract whereas steaming or boiling resulted in a 324 significant $(\mathrm{p}<0.05)$ reduction in the yield of extract to as low as $0.26 \%$ (Table 2$)$. The 325 reduction of vitamin levels during processing and cooking can vary largely depending on the 
cooking method and type of food (Leskova et al., 2006). Studies have shown that phenolic compounds are sensitive to heat, whereby boiling of vegetables for few minutes could cause a significant loss of phenolic content which can leach into boiling water (Amin et al., 2006). $\mathrm{Xu}$ and Chang (2008) reported a $40-50 \%$ loss in the TPC of legumes due to leaching of 330 phenolics in boiling water whereas Oboh (2005) found up to $200 \%$ increase in the phenolic 331 content of boiled tropical green leafy vegetables. Reduction in TPC was also found in other vegetables such as broccoli, kale and spinach (Zhang and Hamauzu, 2004; Ismail et al., 2004). These authors stated the probable reason was due to dissolution of polyphenols into cooking water which could be the case with $H$. elongata as it requires long cooking times to become edible. Although microwave cooking has been reported to be the most deleterious with respect to the antioxidant properties of vegetables (Sultana et al., 2008), the results in the present study were encouraging as microwaving increased the TPC by $22.49 \%(450 \mathrm{~W})$ and $36.58 \%(900 \mathrm{~W})$, as compared to fresh.

In order to reduce the cooking time and eventual loss of phytochemicals, drying was used as a pre-treatment. The process of drying in itself was not detrimental as a drying period of $12 \mathrm{~h}$ and $24 \mathrm{~h}$ retained 80.1 and $85.96 \%$ of the original phenolic content as compared to fresh seaweed. Possible losses could be attributed to stressing the plant during the drying process due to loss of water through the cell walls. Moreover, drying for 12 and $24 \mathrm{~h}$ before boiling not only reduced the cooking time but also the loss in TPC. Drying for $24 \mathrm{~h}$ before boiling at $100^{\circ} \mathrm{C}$ decreased cooking time by 15 mins and reduced the loss of total phenols by $8.83 \%$, as compared to boiling at $100^{\circ} \mathrm{C}$ without a drying pre-treatment. Drying as a pre-treatment was not effective for steaming as $44.19 \%$ reduction in TPC was seen when seaweed was dried for $24 \mathrm{~h}$ followed by steaming $(\mathrm{p}<0.05)$. Microwaving was not carried out on dried seaweeds as it was not a hydrothermal process and therefore re-hydration would not take place. 
350 Although heat processing seriously degraded the quality of seaweed, an interesting 351 observation was an increase in the potency of the extract (Fig. 1 (B)). When the activity of

352 the heat processed extract was compared in terms of per gram dried extract, it was found that 353 boiling at $80^{\circ} \mathrm{C}$ and $100^{\circ} \mathrm{C}$ resulted in an increase of $104.03 \%$ and $71 \%$ TPC per $\mathrm{g}$ of dried extract, respectively, as compared to fresh $(\mathrm{p}<0.05)$. Fresh H. elongata contained $55.75 \mathrm{mg}$ GAE/g of extract. Drying for 12 and $24 \mathrm{~h}$ led to a significant decrease in TPC up to $22.42 \%$ as compared to fresh $(\mathrm{p}<0.05)$. Drying pre-treatment for $12 \mathrm{~h}$ followed by boiling at 80 and $100^{\circ} \mathrm{C}$ for 30 and 25 mins, respectively, had a 161.43 and $125.11 \%$ increase per $\mathrm{g}$ of extract as compared to fresh samples $(\mathrm{p}<0.05)$. Samples pre-treated by drying for $24 \mathrm{~h}$ followed by boiling at $100^{\circ} \mathrm{C}$ for $20 \mathrm{~min}$ increased the TPC by $165.32 \%$ as compared to fresh. Drying of

$360 \mathrm{H}$. elongata for $24 \mathrm{~h}$ followed by boiling at $80^{\circ} \mathrm{C}$ for $30 \mathrm{mins}$ had the most significant effect $361(\mathrm{p}<0.05)$ on the TPC of all treatments resulting in $173.99 \%$ increase in TPC. Steaming for 45 mins had a $36.62 \%$ decrease in TPC per g of extract while a drying pre-treatment before steaming for 50 mins had a $40 \%$ decrease. Microwaving at $450 \mathrm{~W}$ caused no significant

364 increase in the TPC per $\mathrm{g}$ of extract as compared to fresh $(\mathrm{p}<0.05)$, while microwaving at $900 \mathrm{~W}$ increased the TPC to $82 \mathrm{mg} \mathrm{GAE} / \mathrm{g}$ of extract (47.08\% increase). As the TPC of $H$. elongata per g of extract was increased due to processing, a lower concentration of the extract would be required to have a potential effect on preventing oxidation in food products which is a promising finding.

\subsection{Effect of processing on DPPH radical scavenging activity}

371 The results of the DPPH free radical scavenging ability of the seaweed processed under different conditions are shown in Table 2. DPPH reagent has been used extensively for investigating the free radical scavenging activities of compounds (Shon et al., 2003). The

374 results indicated that free radical scavenging ability of the processed seaweeds ranged from 
375

376

377

378

379

380

381

382

383

384

385

386

387

388

389

390

391

392

393

394

395

396

397

398

52.51 to $100 \%$ (concentration $100 \mu \mathrm{g} / \mathrm{ml}$ extract) with extracts from seaweed dried for $12 \mathrm{~h}$ followed by boiling at $100^{\circ} \mathrm{C}$ being most effective. Significant differences $(\mathrm{p}<0.05)$ in DPPH values were found for all processing treatments. At $100 \mu \mathrm{g} / \mathrm{ml}$ extract concentration, drying led to slight decrease in DPPH radical scavenging activity from $75.5 \%$ to $74.69 \%$ (12 h) and $67.87 \%(24 \mathrm{~h})$ while boiling led to a significant increase $(\mathrm{p}<0.05)$. Boiling at $100^{\circ} \mathrm{C}$ increased DPPH scavenging by $23.89 \%$, from 75.5 to $93.54 \%$. Drying of $H$. elongata for $12 \mathrm{~h}$ followed by boiling at $100^{\circ} \mathrm{C}$ had the most significant increase in antioxidant activity as $100 \%$ inhibition of the DPPH radical was achieved with $100 \mu \mathrm{l} / \mathrm{ml}$ of extract. Steaming significantly reduced the DPPH radical scavenging activity $(\mathrm{p}<0.05)$ to $52.51 \%$. Extracts from $H$. elongata given drying pre-treatments followed by steaming had 53.79\% (12 h) and $53.5 \%(24 \mathrm{~h})$ scavenging of the DPPH radical. Seaweed microwaved at $450 \mathrm{~W}$ had $76.29 \%$ activity against DPPH radical while microwaving at $900 \mathrm{~W}$ had $75.35 \%$ activity.

DPPH results are often interpreted as the "efficient concentration" or $\mathrm{EC}_{50}$ value, which is defined as the concentration of substrate that causes 50\% loss of the DPPH activity (Molyneux, 2004). The $\mathrm{EC}_{50}$ values of $\mathrm{DPPH}$ radical scavenging activity from dried methanolic extracts of seaweeds are also presented in Table 2. Processing of $H$. elongata resulted in significantly different $\mathrm{EC}_{50}$ values $(\mathrm{p}<0.05)$, depending upon treatment. The $\mathrm{EC}_{50}$ levels ranged from 12.5 to $100 \mu \mathrm{g} / \mathrm{ml}$ of extract with all treatments in which boiling was found to have the most effective $\mathrm{EC}_{50}$ values $(12.5 \mu \mathrm{g} / \mathrm{ml}$ of extract). Extracts from fresh seaweed had an $\mathrm{EC}_{50}$ of $25 \mu \mathrm{g} / \mathrm{ml}$. Drying of seaweed led to a significant $(\mathrm{p}<0.05)$ reduction in the DPPH radical scavenging activity of the extract to $50 \mu \mathrm{g} / \mathrm{ml}(12$ and $24 \mathrm{~h})$. Steaming had the most detrimental effect on the DPPH radical scavenging activity of the extract as $100 \mu \mathrm{g} / \mathrm{ml}$ was required to reduce the DPPH radical by $50 \%$ and activity at $100 \mu \mathrm{g} / \mathrm{ml}$ concentration was almost half that of the most effective processed seaweed (53.5 and 100\%, 
respectively). There was no significant difference between microwaved seaweed extracts compared to fresh $(\mathrm{p}>0.05)$ as all had an $\mathrm{EC}_{50}$ value of $25 \mu \mathrm{g} / \mathrm{ml}$.

\subsection{Effect of processing on total flavonoid content}

The bioavailability of phytochemicals is influenced by the matrix and microstructure of the

403 food they occur in, the storage conditions (light, oxygen, and temperature regime) and thermal processing they are subjected. As a consequence, knowledge of the content and stability of phytochemicals in foods after processing is essential to evaluate the nutritional value of foods rich in these phytochemicals, like seaweed to (Parada and Aguilera, 2007).

The total flavonoid content (TFC) of processed whole H. elongata is presented in Fig. 2 (A). The TFC of fresh H. elongata was $53.18 \mathrm{mg}$ QE/100 g FW. Drying for 12 and $24 \mathrm{~h}$ had no significant effect on the TFC as there was only a slight increase of 0.72 and $0.25 \%$, respectively $(\mathrm{p}>0.05)$. All treatments which included boiling significantly reduced the TFC,

411 within a range of 88.86 to $90.18 \%$. This highest reduction was seen in fresh seaweed boiled at $100^{\circ} \mathrm{C}$ which led to a $90.18 \%$ reduction in TFC $(\mathrm{p}<0.05)$. Flavonoids commonly accumulate in epidermal cells of plant organs, being found as glycosides and in non-glycosidic forms

414 (aglycones) (Sakihama et al., 2002). Release of flavonoids and increased chemical extraction 415 of these compounds could be induced by the effect of boiling (Olivera et al., 2008). This release of flavonoids coupled with contact and leaching into water could have resulted in high

417 reduction in TFC for boiled samples. The results of the present study are similar to Olivera et 418 al. (2008) who found that boiling decreased TFC in brussels sprouts. Steaming also led to a 419 significant reduction in TFC compared to fresh but this was significantly less as compared to 420 boiled seaweeds $(\mathrm{p}<0.05)$. Steaming retained $17.4 \%$ more TFC than boiled samples as compared to fresh samples. This could be due to the fact that steamed seaweeds were not in direct contact with water which resulted in considerably less leaching of flavonoids. 
the TFC by $10.65 \%$ in whole H. elongata $(\mathrm{p}<0.05)$. These results are in line with Francisco et al. (2010) and Rodrigues et al. (2009) who also reported significant losses of flavonoids up to $67 \%$ in cooked conventional vegetables.

Total flavonoid content of processed H. elongata extracts are presented in Fig. 2 (B). Extracts from fresh $H$. elongata contained $42.29 \mathrm{mg} \mathrm{QE} / \mathrm{g}$ of extract. All treatments significantly changed the TFC content as compared to fresh $(\mathrm{p}<0.05)$. Simple drying for 12 and $24 \mathrm{~h}$ significantly reduced $(\mathrm{p}<0.05)$ the TFC in the range of $2.45 \%$ to $9.35 \%$ whereas boiling at $80^{\circ} \mathrm{C}$ and $100^{\circ} \mathrm{C}$ resulted in an increase up to $15.76 \%$. However, a combination of drying pretreatment followed by boiling had the most significant effect on the TFC of $H$. elongata. Drying for $12 \mathrm{~h}$ followed by boiling at $80^{\circ} \mathrm{C}$ and $100^{\circ} \mathrm{C}$ resulted in 18.72 and $21.67 \%$ increase in TFC, respectively $(\mathrm{p}<0.05)$. Drying for $24 \mathrm{~h}$ followed by boiling at $100^{\circ} \mathrm{C}$ for 20 mins had a $26.6 \%$ increase in TFC. The most significant increase of $32.02 \%$ was seen in samples dried for $24 \mathrm{~h}$ followed by boiling at $80^{\circ} \mathrm{C}$ for 30 mins. Steaming alone and in combination with 12 and $24 \mathrm{~h}$ drying pre-treatments resulted in 14, 11.43 and $11.98 \%$ increase in TFC, respectively. The increase in the case of microwaved samples ranged from $8.72 \%$ to $14.29 \%$.

\subsection{Effect of processing on total condensed tannin content}

Phlorotannins are a group of phenolic compounds which are restricted to polymers of phloroglucinol and have been identified from several brown algae. Many studies have shown that phlorotannins are the only phenolic group detected in brown algae (Jormalainen and

445 Honkanen, 2004; Koivikko et al., 2007). Total condensed tannin content (TTC) of processed H. elongata can be seen in Fig. 3 (A). Condensed tannins of the studied seaweeds ranged 447 from 70.61 to $5.5 \mathrm{mg} \mathrm{QE} / 100 \mathrm{~g}$ FW. Fresh $H$. elongata contained $70.05 \mathrm{mg} \mathrm{CE} / 100 \mathrm{~g} \mathrm{FW}$ 448 while drying for 12 and 24 h reduced the TTC by 2.92 and $4.73 \%$, respectively. 
449 Similarly to total flavonoid contents, TTC was significantly reduced upon boiling $(\mathrm{p}<0.05)$.

450 Boiling at $80^{\circ} \mathrm{C}$ for 40 mins significantly reduced the TTC from 70.05 to $6.22 \mathrm{mg} \mathrm{CE} / 100 \mathrm{~g}$ 451 FW (91.11\% reduction). The most significant reduction of $92.13 \%$ in TTC was seen in $H$. 452 elongata boiled at $100^{\circ} \mathrm{C}$ for 35 mins $(\mathrm{p}<0.05)$. Similar to TFC, steaming had a lower 453 reduction of TTC as compared to boiling. Steaming retained $40.5 \%$ more TTC than boiled 454 samples as compared to fresh $(\mathrm{p}<0.05)$. Microwaving at 450 and $900 \mathrm{~W}$ had a 20.27 and $45522.54 \%$ reduction in TTC, respectively $(\mathrm{p}<0.05)$. The basis of the significant decrease in 456 cooked seaweeds could also be attributed to the possible break-down of tannins present in the 457 seaweed to simple phenol (Akindahunsi and Oboh, 1999). Khandelwal et al. (2010) and Somsub et al. (2008) also found decreases in tannin levels of cooked legumes and vegetables. In contrast to TPC and TFC, a significant reduction in the total condensed tannins of 460 processed $H$. elongata extracts was observed as compared to fresh (Fig. 3 (B)). Extracts from 461 fresh $H$. elongata contained $55.7 \mathrm{mg} \mathrm{CE} / \mathrm{g}$, while drying for 12 and $24 \mathrm{~h}$ had 7.73 and $8.65 \%$ 462 reduction in $\mathrm{TTC}$, respectively. Boiling at $80^{\circ} \mathrm{C}$ for $40 \mathrm{mins}$ led to a $58.97 \%$ reduction in TTC while $62.89 \%$ reduction was seen in $H$. elongata boiled at $100^{\circ} \mathrm{C}$ for 35 mins. Drying 464 pre-treatment followed by boiling also had significant losses of TTC but less than that of 465 boiled seaweed. Drying for $12 \mathrm{~h}$ before boiling at 80 and $100^{\circ} \mathrm{C}$ had 53.52 and $53.78 \%$ 466 reduction respectively. Drying for $24 \mathrm{~h}$ followed by boiling at $80^{\circ} \mathrm{C}$ for $30 \mathrm{~min}$ caused a loss of TTC by $55.71 \%$ while drying for $24 \mathrm{~h}$ in combination with boiling at $100^{\circ} \mathrm{C}$ for 20 mins had a $55.91 \%$ reduction from 55.7 to $24.55 \mathrm{mg}$ CE/g of extract. Steaming resulted in $18.91 \%$ reduction while in combination with a drying pre-treatment there was a $28 \%$ reduction as compared to extracts from fresh $\mathrm{H}$. elongata. Microwaving at 450 and $900 \mathrm{~W}$ for 30 and $20 \mathrm{~s}$ had a 19.14 and $16.88 \%$ reduction in TTC, respectively $(\mathrm{p}<0.05)$. 
474 Consumers are concerned about the safety of foods containing synthetic preservatives. This 475 has put pressure on the food industry and has fuelled research into the discovery of 476 alternative natural antimicrobials (Shan et al., 2007). Antimicrobial activity of processed 477 seaweed extracts was studied in order to analyse the effect of food processing on their 478 activity. The entire yield of extract from $5 \mathrm{~g}$ original weight of each of the processed 479 seaweeds were dissolved in $2.5 \mathrm{ml}$ TSB and utilized in the assay. Therefore, different 480 concentrations were achieved at each dilution level as can be seen in Table 3. In the present 481 study antimicrobial activity was tested against common food spoilage (E. faecalis and $P$. 482 aeruginosa) and food pathogenic (L. monocytogenes and S. abony) bacteria. These organisms 483 were studied after discussions with the Food Safety Authority of Ireland because they have 484 been identified as being problematic in the Irish food industry. The entire spectrum of 485 inhibitory effects is reported as outlined by Dubber and Harder (2008).

L. monocytogenes is a Gram-positive pathogenic bacterium commonly isolated from foods in many countries including Ireland (Chitlapilly-Dass et al., 2010). The percentage inhibition of the processed seaweed extracts against L. monocytogenes are presented in Table 4 and the concentrations of extract for each dilution of processed $H$. elongata are outlined in Table 3.

490 At highest extract concentrations, extract from fresh seaweed and those dried for 12 and $24 \mathrm{~h}$ $491(31.44,32.47$ and $34.77 \mathrm{mg} / \mathrm{ml}$, respectively) had $100 \%$ inhibition against L. monocytogenes. 492 Any processing treatment which included boiling of $H$. elongata had weak activity against $L$. 493 monocytogenes ( $<25 \%$ inhibition), however extract concentrations were lower most likely 494 due to leaching of phytochemicals during the boiling procedure. Extracts of steamed seaweed 495 had strong activity against L. monocytogenes at the highest dilution tested (96.34\% inhibition 496 at $34 \mathrm{mg} / \mathrm{ml}$ ). However when drying was used as a pre-treatment before steaming there was 497 less than half the inhibition against L. monocytogenes; $43.25 \%(31 \mathrm{mg} / \mathrm{ml})$ and $43.85 \%(29.3$ $498 \mathrm{mg} / \mathrm{ml}$ ) for 12 and $24 \mathrm{~h}$ dried samples, respectively. Microwaving at 450 and $900 \mathrm{~W}$ 
499 produced extracts with strong inhibition against L. monocytogenes in the first dilution (97.24 500 and $97.26 \%$ inhibition at 37.56 and $43.37 \mathrm{mg} / \mathrm{ml}$ extract, respectively). As the yield of

501 microwaved $H$. elongata extract was higher than other treatments, this would suggest that the 502 extract is in fact slightly less potent than those of fresh seaweed. Extracts from fresh $H$. 503 elongata at the first concentration tested $(31.44 \mathrm{mg} / \mathrm{ml})$ were the most effective of the 504 processed seaweeds overall.

505 There was no significant difference $(\mathrm{p}>0.05)$ between the first and second dilutions of fresh H. elongata extract tested against L. monocytogenes $(15.72 \mathrm{mg} / \mathrm{ml})$ which again had $100 \%$ 507 inhibition in the second dilution. An inhibition activity of 89.88 to $92.99 \%$ was obtained by 508 dried extracts whereas extracts from boiled seaweeds had completely lost the antimicrobial 509 activity. Drying pre-treatment before boiling seemed to maintain weak antimicrobial activity 510 of the extracts in the range of 9.81 to $15.89 \%$ in the second dilution as compared to $0 \%$.

511 Extracts from steamed seaweed at the second dilution of $17 \mathrm{mg} / \mathrm{ml}$ had strong activity against 512 L. monocytogenes giving $96.24 \%$ inhibition. Seaweeds which received a drying pre-treatment 513 (12 and $24 \mathrm{~h}$ ) before steaming had significantly less antimicrobial activity against $L$. 514 monocytogenes in the second dilution with inhibition levels of 34.14 and $34.15 \%$ at 15.5 and $51514.65 \mathrm{mg} / \mathrm{ml}$, respectively $(\mathrm{p}>0.05$ ). Extracts from the second dilution of microwaved seaweed had $82.9 \%(450 \mathrm{~W})$ and $81.45 \%(900 \mathrm{~W})$ inhibition against L. monocytogenes at

$517 \quad 18.78$ and $21.74 \mathrm{mg} / \mathrm{ml}$ extract concentrations, respectively. At the third and fourth dilutions; 518 although fresh seaweeds still had $98 \%$ activity, all processed seaweeds had significantly less 519 inhibition $(\mathrm{p}<0.05)$.

522 Salmonella is a Gram-negative food-borne pathogenic bacterium and has become one of the 523 most important causes of acute enterocolitis throughout the world. Salmonellosis is caused by 
any of over 2300 serovars of Salmonella (Wong et al., 2000; Lee et al., 2001). Fresh H. elongata had the highest activity against $S$. abony as can be seen in Table 5. However, overall, the processed extracts were least effective against $S$. abony, and no processing treatment achieved $100 \%$ inhibition of the bacteria. A potential cause is that $S$. abony is

528 Gram-negative, as there are significant differences in the outer layers of Gram-negative and

529 Gram-positive bacteria. Gram-negative bacteria possess an outer membrane and a unique 530 periplasmic space which is not found in Gram-positive bacteria (Nikaido, 1996; Duffy and 531 Power, 2001). Antibacterial substances can easily destroy the bacterial cell wall and 532 cytoplasmic membrane and result in a leakage of the cytoplasm and its coagulation (Kalemba 533 and Kunicka, 2003).

534 Fresh $H$. elongata extracts had activity which ranged from 87.03 to $37.18 \%$ in the first to 535 fourth dilutions. Seaweed which had been dried for 12 and $24 \mathrm{~h}$ had moderate activity against S. abony in the first dilution of extract but had weak activity from the second dilution onwards $(<50 \%$ inhibition). Any processing treatment which included boiling had weak activity against $S$. abony with a maximum of $22.11 \%$ inhibition. Extracts from steamed $H$. elongata had strong activity in the first and second dilutions ( $>90 \%)$ and moderate activity thereafter. Drying of seaweed before steaming led to a significant reduction $(\mathrm{p}<0.05)$ in antimicrobial activity as compared to steaming alone against S. abony (44\% inhibition) in the

542 first dilution and weak activity in subsequent dilutions. Activity of microwaved H. elongata extracts at 450 and $900 \mathrm{~W}$ ranged from strong $(\leq 94.4 \%)$ to weak $(<50 \%)$ against S. abony.

5453.7 Antimicrobial activity of processed H. elongata extracts against E. faecalis

546 The Gram-positive bacterium E. faecalis is a natural member of the human and animal 547 gastrointestinal flora. This bacterium is an indicator of faecal contamination and has been 548 detected in food, milk and drinking water (Rincé et al., 2003). Antimicrobial activity of 
549 processed $H$. elongata extracts against $E$. faecalis are outlined in Table 6. Fresh $H$. elongata

550 extracts had more than $99 \%$ antimicrobial activity until the second dilution and moderate

551 activity in the third and fourth dilutions (87.03 and 78.02\%, respectively). Dried seaweed

552 extracts had very strong (100\%) and strong (95.4\%) activity in the first dilution for 12 and 24

$553 \mathrm{~h}$, respectively, however this level was halfed in the second dilution with $39.24 \%$ (12 h) and

$55453.01 \%$ inhibition $(24 \mathrm{~h})$. Extracts from boiled seaweeds had less than $10 \%$ activity in the

555 first two dilutions and was completely lost in lower dilutions. A drying pre-treatment before

556 boiling retained more of the bioactivity $(\mathrm{p}<0.05)$ of the extract, for example extracts of $H$.

557 elongata processed by drying for $12 \mathrm{~h}$ followed by boiling at $80^{\circ} \mathrm{C}$ for $30 \mathrm{mins}$ had $51.45 \%$

558 inhibition. Extracts from steamed $H$. elongata had strong activity in the first and second

559 dilutions $(\leq 95.21 \%)$ and moderate activity thereafter. Drying of seaweed before steaming led

560 to a significant reduction $(\mathrm{p}<0.05)$ in antimicrobial activity as compared to steaming alone

561 against $E$. faecalis also ( $\leq 44.57 \%$ inhibition). Extracts of microwaved $H$. elongata had strong

562 activity in the first dilution $(\leq 95.81 \%)$ while extracts from the second dilution onwards were

563 significantly less effective with activity below $53.07 \%$.

564

5653.8 Antimicrobial activity of processed $H$. elongata extracts against $P$. aeruginosa

$566 P$. aeruginosa is a ubiquitous Gram-negative food spoilage bacterium with great adaptability

567 and metabolic versatility. P. aeruginosa can attach onto a variety of surfaces and in a variety

568 of niches including the food processing environments by forming biofilms, which are more

569 resistant to environmental stresses, host-mediated responses, sanitizing agents, and

570 antimicrobial agents (Bremer et al., 2001). Antimicrobial activity of processed $H$. elongata

571 extracts against $P$. aeruginosa are presented in Table 7. Similar to Gram-negative S. abony,

572 there was also no processed seaweed extract which gave $100 \%$ inhibition against $P$.

573 aeruginosa. Antimicrobial activity of extracts from fresh $H$. elongata were strong in the first 
574 dilution with $96.39 \%$ inhibition and moderate in the subsequent dilutions. Seaweed which 575 had been dried for 12 and $24 \mathrm{~h}$ achieved a maximum activity of $94.05 \%$. Boiling led to a 576 significant reduction in antimicrobial activity of extracts against $P$. aeruginosa. Activity of 577 steamed $H$. elongata extracts ranged from 95.32 to $77.54 \%$ in the first to fourth dilutions.

578 Extracts from seaweed given a drying pre-treatment followed by steaming had less than half 579 the level of activity as compared to steaming alone. The antimicrobial activity of microwaved 580 extracts ranged from strong to weak (95.73 to $33.16 \%$ ). In the present study, extracts from 581 fresh seaweeds had strong antimicrobial activity at a concentration as low as $3.93 \mathrm{mg} / \mathrm{ml}$. In 582 the majority of reports on antimicrobial activities of seaweed extracts, bacterial growth 583 inhibiting activities were investigated using standard agar disc diffusion assays (Bansemir et 584 al., 2006; Kuda et al., 2007; Shanmughapriya et al., 2008). There have been few quantitative reports on antimicrobial activity of seaweed extracts, however from those available; the results of the present study have been shown to be more effective than reported by Dubber and Harder (2008). These authors found extracts of Ceramium rebrum and Laminaria digitata had strong activity at 10 and $31 \mathrm{mg} / \mathrm{ml}$, respectively, which is less potent than those of fresh seaweeds in the present study.

\section{Conclusion}

592 The findings of the present study indicate that the method of processing significantly

593 influences the concentrations of phytochemicals, antioxidant and antimicrobial parameters in

594 H. elongata. Consumption of H. elongata is dependant on some heat treatment in order to 595 achieve an edible texture. Since cooking invariably leads to a loss of antioxidant properties, a compromise must be reached between palatability and nutrition. It was found that a combination of drying followed by boiling reduced cooking time and led to less leaching of

598 phytochemicals. In terms of antioxidant activity of extract, a drying pre-treatment followed 
599 by boiling enhanced the phenolic content per gram of extract and as a result less amount of 600 the extract would be required to have a significant effect in food products. Processing

601 significantly affects the antimicrobial activity of extracts from $H$. elongata. Extracts from

602 fresh $H$. elongata had the highest antimicrobial activity against L. monocytogenes, S. abony, 603 E. faecalis and $P$. aeruginosa with good inhibition as low as $4.16 \mathrm{mg} / \mathrm{ml}$ extract. A better 604 knowledge of how these processing conditions affects the phytochemical compounds of 605 interest is of pivotal importance. Reduction in the moisture content and cooking time also 606 could have benefits in reducing transport and energy costs. Losses of health-related 607 phytochemicals are thus likely to be a function of drying and cooking parameters such as 608 time, temperature and degree of wounding stress to the plant during these processes.

609

610 Acknowledgements

611 The authors acknowledge funding from the Dublin Institute of Technology under the 612 ABBEST Programme. The authors thank Denis Benson and Noel Grace from the Dublin 613 Institute of Technology for their technical support and Manus Mc Gonagle for the supply of 614 fresh seaweed.

615

616

617

618

619

620

621

622

623 


\section{References}

627 Akindahunsi, A.A. and Oboh, G. 1999. Effect of some post-harvest treatments on the 628 bioavailability of zinc from some selected tropical vegetables. La Riv. Ital. Delle Sost. Gras. $629 \quad 285-287$.

630 Akoh, C.C. and Min, B.D. 1997. Food Lipid Chemistry. In: Nutrition Biotechnology Marcel 631 Dekker Inc., New York.

632 Al-Azzawie, H.F. and Mohamed-Saiel, S.A. 2006. Hypoglycemic and antioxidant effect of 633 oleuropein in alloxan-diabetic rabbits. Life Sci. 78, 1371-1377.

634 Amic, D., Davidovic-Amic, D. and Beslo, N. 2003. Trinajstic, Structure-radical scavenging 635 activity relationship of flavonoids. Croat. Chem. Acta. 76, (1), 55-61.

636 Amin, I., Norazaidah Y. and Emmy Hainida, K. I. 2006. Antioxidant activity and phenolic 637 content of raw and boiled Amaranthus species. Food Chem. 94, 47-52.

638 Aruoma, I.O. 1999. Antioxidant action of plant foods. Use of oxidative DNA damage, as a 639 tool for studying antioxidant efficacy. Free Rad. Res. 30, 419-427.

640 Bansemir, A., Blume, M., Schroder, S. and Lindequist, U. 2006. Screening of cultivated 641 seaweeds for antibacterial activity against fish pathogenic bacteria. Aquacult. 252, 79-84.

642 Bremer, P.J., Monk, I. and Osborne, C.M. 2001. Survival of Listeria monocytogenes attached 643 to stainless steel surfaces in the presence or absence of Flavobacterium spp. J. Food Prot. 64, $644 \quad 1369-1376$.

645 Chandini, S.K., Ganesan, P. and Bhaskar, N. 2008. In vitro activities of three selected brown 646 seaweeds of India. Food Chem. 107, 707-713.

647 Chiewchan, N., Praphraiphetch, C. and Devahastin, S. 2010. Effect of pretreatment on 648 surface topographical features of vegetables during drying. J. Food Eng. 101, 41-48. 
649 Chitlapilly-Dass, S., Abu-Ghannam, N., Antony-Babu, S. and Cummins, E.J. 2010. Ecology

650 and molecular typing of L. monocytogenes in a processing plant for cold-smoked salmon in

651 the Republic of Ireland. Food Res. Int. 43, 1529-1536.

652 Cox, S., Gupta, S. and Abu-Ghannam, N. 2010. An assessment of the antioxidant and 653 antimicrobial properties of six species of edible Irish seaweeds. Int. Food Res. J. 17, 205-220.

654 Duan, X.J., Zhang, W.W., Li, X.M. and Wang, B.G. 2006. Evaluation of antioxidant property 655 of extract and fractions obtained from a red alga, Polysiphonia urceolata. Food Chem. 95, $656 \quad 37-43$.

657 Dubber, D. and Harder, T. 2008. Extracts of Ceramium rubrum, Mastocarpus stellatus and 658 Laminaria digitata inhibit growth of marine and fish pathogenic bacteria at ecologically 659 realistic concentrations. Aquacult. 274, 196-200.

660 Duffy, C.F. and Power, R.F. 2001. Antioxidant and antimicrobial properties of some Chinese 661 plant extracts. Int. J. Antimicrob. Agents. 17, 527-529.

662 Francisco, M., Velasco, P., Moreno, D.A., Garcia-Viguera, C. and Cartea, M.E. 2010. 663 Cooking methods of Brassica rapa affect the preservation of glucosinolates, phenolics and 664 vitamin C. Food Res. Int. 43, 1455-1463.

665 Gahler, S., Otto K. and Bohm, V. 2003. Alterations of vitamin C, total phenolics, and 666 antioxidant capacity as affected by processing tomatoes to different products. J. Agricult. 667 Food Chem. 51, 7962-7968.

668 Ismail, A., Marjan, Z.M. and Foong, C.W. 2004. Total antioxidant activity and phenolic 669 content in selected vegetables. Food Chem. 87, 581-586.

670 Jormalainen, V. and Honkanen, T. 2004. Variation in natural selection for growth and 671 phlorotannins in the brown alga Fucus vesiculosus. Journal Evolution. Biol. 17 (4), 807-820.

672 Julkunen-Titto, R. 1985. Phenolic constituents in the leaves of northern willow: Methods for 673 the analysis of certain phenolics. J. Agricult. Food Chem. 33, 213-217. 
674 Kalemba, D. and Kunicka, A. 2003. Antibacterial and antifungal properties of essential oils. 675 Curr. Medic. Chem. 10, 813-829.

676 Khandelwal, S., Udipi, S.A. and Ghugre, P. 2010. Polyphenols and tannins in Indian pulses:

677 Effect of soaking, germination and pressure cooking. Food Res. Int. 43, 526-530.

678 Koivikko, R., Loponen, J., Pihlaja, K. and Jormalainen, V. 2007. High-performance liquid 679 chromatographic analysis of phlorotannins from the brown alga Fucus vesiculosus. 680 Phytochem. Anal. 18 (4), 326-332.

681 Kris-Etherton, P.M., Hecker, K.D., Bonanome, A. Coval, S.M., Binkoski, A.E. and Hilpert K. 682 F. 2002. Bioactive compounds in foods: Their role in the prevention of cardiovascular disease 683 and cancer. Amer. J. Med. 113, 71-88.

684 Kuda, T., Kunii, T., Goto, H., Suzuki, T. and Yano, T. 2007. Varieties of antioxidant and 685 antibacterial properties of Ecklonia stolonifera and Ecklonia kurome products harvested and 686 processed in the Noto peninsula, Japan. Food Chem. 103, 900-905.

687 Kuda, T., Tsunekawa, M., Goto, H. and Araki, Y. 2005. Antioxidant properties of four edible 688 algae harvested in the Noto Peninsula, Japan. J. Food. Comp. Anal. 18, 7, 625-633.

689 Lee, W.C., Lee, M.J., Kim, J.S. and Park, S.Y. 2001. Foodborne illness outbreaks in Korea 690 and Japan studied retrospectively. J. Food Prot. 64 (6), 899-902.

691 Leskova, E. Kubikova, J., Kovacikova, E., Kosicka, M., Porubska, J. and Holcikova, K. 692 2006. Vitamin losses: Retention during heat treatment and continual changes expressed by 693 mathematical models. J. Food. Comp. Anal. 19 (4), 252-276.

694 Lim, Y.Y. and Murtijaya, J. 2007. Antioxidant properties of Phyllanthus amarus extracts as 695 affected by different drying methods. LWT- Food Sci. Technol. 40, 1664-1669.

696 Matsukawa, R., Dubinsky, Z., Kishimoto, E., Masaki, K.F.Y. and Takeuchi, T. 1997. A 697 comparison of screening methods for antioxidant activity in seaweeds. J. Appl. Phycol. 9, 2969835. 
699 Molyneux, P. 2004. The use of the stable free radical diphenylpicrylhydrazyl (DPPH) for 700 estimating antioxidant activity. J. Sci. Technol. 26 (2), 211-219.

701 Nikaido, H. 1996. Outer membrane. In: Neidhardt, F.C. (Ed.), Escherichia coli and

702 Salmonella typhimurium: Cellular and Molecular Biology. Amer. S. Microbiol. Press.

703 Washington, D.C., pp. 29-47.

704 Nishinari, K. 2004. Rheology, food texture, and mastication. J. Text. Stud. 35, 113-124.

705 Oboh, G. 2005. Effect of boiling on the antioxidant properties of some tropical green leafy 706 vegetables. LWT. 38, 513-517.

707 Olivera, D.F., Vina, S.Z., Marani, C.M., Ferreyra, R.M., Mugridge, A., Chaves, A.R. and 708 Mascheroni, R.H. 2008. Effect of boiling on the quality of Brussels sprouts (Brassica 709 oleracea L. gemmifera DC) after frozen storage. J. Food Eng. 84, 148-155.

710 Parada, J. and Aguilera, J.M. 2007. Food microstructure affects the bioavailability of several 711 nutrients. J. Food Sci. 72, R21-R32.

712 Reaven, P.D. and Witzum, J.L. 1996. Oxidised LDL in atherogenesis. Role of dietary 713 modification. Ann. Rev. Nutri. 16, 51-71.

714 Rincé, A. Le Breton, Y., Verneuil, N., Giard, J.C., Hartke, A. and Auffray, Y. 2003. 715 Physiological and molecular aspects of bile salt response in Enterococcus faecalis. Int. J. 716 Food Microbiol. 88, 207-213

717 Rodrigues, A.S., Pérez-Gregorio, M.R., Garcia-Falcon, M.S. and Simal-Gándara, J. 2009.

718 Effect of curing and cooking on flavonols and anthocyanins in traditional varieties of onion

719 bulbs. Food Res. Int. 42, 1331-1336.

720 Rungapamestry, V., Duncan, A.J., Fuller, Z. and Ratcliffe, B. 2007. Effect of cooking 721 Brassica vegetables on the subsequent hydrolysis and metabolic fate of glucosinolates. Proc.

722 Nutri. Soc. $66(1), 69-81$. 
723 Sakihama, Y., Michael, F., Cohen, M.F., Stephen, C., Grace, S.C. and Yamasaki, H. 2002.

724 Plant phenolic antioxidant and prooxidant activities: phenolics-induced oxidative damage

725 mediated by metals in plants. Toxicol, 177, 67-80.

726 Shan, B., Cai, Y.Z., Brooks, J.D. and Corke, H. 2007. The in vitro antibacterial activity of

727 dietary spice and medicinal herb extracts. Int. J. Food Microbiol. 117, 112-119.

728 Shanmughapriya, S., Manilal, A., Sujith, S., Selvin, J., Segal-Kiran, G. and

729 Natarajaseenivasan, K. 2008. Antimicrobial activity of seaweeds extracts against

730 multiresistant pathogens. Annals. Microbiol. 58 (3), 535-541.

731 Shon, M.Y., Kim, T.H. and Sung, N.J. 2003. Antioxidants and free radical scavenging

732 activity of Phellinus baumii (Phellinus of Hymenochaetaceae) extracts. Food Chem. 82, 593733597.

734 Shahidi, F. 2009. Neutraceuticals and functional foods: Whole versus processed foods.

735 Trends Food Sci Tech. 20 (9), 376-387.

736 Shukla, V.K.S, Wanasundara, P.K.J.P.D. and Shahidi, F. 1997. Natural antioxidants from

737 oilseeds. In: Shahidi, F. (Eds), Natural antioxidants: Chemistry, Health Effects, and

738 Applications. AOCS Press, Champaign, IL, (pp. 97-132).

739 Somsub, W., Kongkachuichai, R., Sungpuag, P. and Charoensiri, P. 2008. Effects of three

740 conventional cooking methods on vitamin $\mathrm{C}$, tannin, myo-inositol phosphates contents in

741 selected Thai vegetables. J. Food Comp. Anal. 21, 187-197.

742 Sultana, B., Anwar, F. and Iqbal, S. 2008. Effect of different cooking methods on the 743 antioxidant activity of some vegetables from Pakistan. Int. J. Food Sci. Technol. 43, 560-567.

744 Taga, M.S., Miller, E.E. and Pratt, D.E. 1984. Chia seeds as a source of natural lipid 745 antioxidants. J. Amer. Oil Chem. Assoc. 61, 928-931.

746 Turkmen, N., Sari, F. and Velioglu, Y.S. 2005. The effect of cooking methods on total 747 phenolics and antioxidant activity of selected green vegetables. Food Chem. 93, 713-718. 
748 Vairappan, C.S., Daitoh, M., Suzuki, M., Abe, T. and Masuda, M. 2001. Antibacterial 749 halogenated metabolites from the Malaysian Laurencia species. Phytochem. 58, 291-297.

750 Volden, J., Borge, G.I.A., Hansen, M., Wicklund, T. and Bengtsson, G.B. 2009. Processing 751 (blanching, boiling, steaming) effects on the content of glucosinolates and antioxidant-related 752 parameters in cauliflower (Brassica oleracea L. ssp. botrytis). LWT- Food Sci. Technol. 42, $753 \quad 63-73$.

754 Watchtel-Galor, S., Wong, K.W. and Benzie, I.F.F. 2008. The effect of cooking on Brassica 755 vegetables. Food Chem. 110, 706-710.

756 Wong, H.C., Liu, S.H., Ku, L.W., Lee, I.Y., Wang, T.K. and Lee, Y.S. 2000. 757 Characterization of Vibrio parahaemolyticus isolates obtained from foodborne illness 758 outbreaks during 1992 through 1995 in Taiwan. J. Food Prot. 63 (7), 900-906.

759 Xu, B. and Chang, S.K.C. 2008. Effect of soaking, boiling and steaming on total phenolic 760 content and antioxidant activities of cool season food legumes. Food Chem. 110, 1-13.

761 Yen, G.C. and Chen, H.Y. 1995. Antioxidant activity of various tea extracts in relation to 762 their antimutagenicity. J. Agricult. Food Chem. 43, 27-37.

763 Zhang, D. and Hamauzu, Y. 2004. Phenolics, ascorbic acid, carotenoids and antioxidant 764 activity of broccoli and their changes during conventional and microwave cooking. Food 765 Chem. 88, 503-509.

766 Zhishen, J., Mengcheng, T. and Jianming, W. 1999. The determination of flavonoid contents 767 in mulberry and their scavenging affects on superoxide radicals. Food Chem. 64, 555-559. 
Tables and Figures

774 Table 1. Instrumental and sensory texture evaluation to determine edible texture level 775 of cooked $\boldsymbol{H}$. elongata

776

\begin{tabular}{lll}
\hline $\begin{array}{l}\text { Cooking time } \\
\text { (mins) }\end{array}$ & $\begin{array}{l}\text { Instrumental texture } \\
(\mathbf{N} / \mathbf{m m})\end{array}$ & $\begin{array}{l}\text { Sensory panel } \\
\text { judgements* }\end{array}$ \\
\hline 0 & $45.33 \pm 1.30$ & Too hard and chewy \\
5 & $40.47 \pm 2.31$ & Too hard and chewy \\
10 & $37.38 \pm 1.93$ & Too hard and chewy \\
15 & $35.89 \pm 0.98$ & Too hard and chewy \\
20 & $34.62 \pm 1.61$ & Too hard and chewy \\
25 & $33.98 \pm 0.79$ & Too hard and chewy \\
30 & $32.40 \pm 0.15$ & Edible \\
35 & $32.11 \pm 0.74$ & Edible \\
40 & $30.42 \pm 1.05$ & Edible \\
45 & $30.22 \pm 0.95$ & Edible \\
50 & $30.09 \pm 1.02$ & Edible \\
\hline
\end{tabular}

777

*Sensory panel judgements were based on the hardness and ease of chew of the seaweed. Each value is presented as mean $\pm \operatorname{SD}(n=6)$. Seaweeds were boiled at $100^{\circ} \mathrm{C}$ 


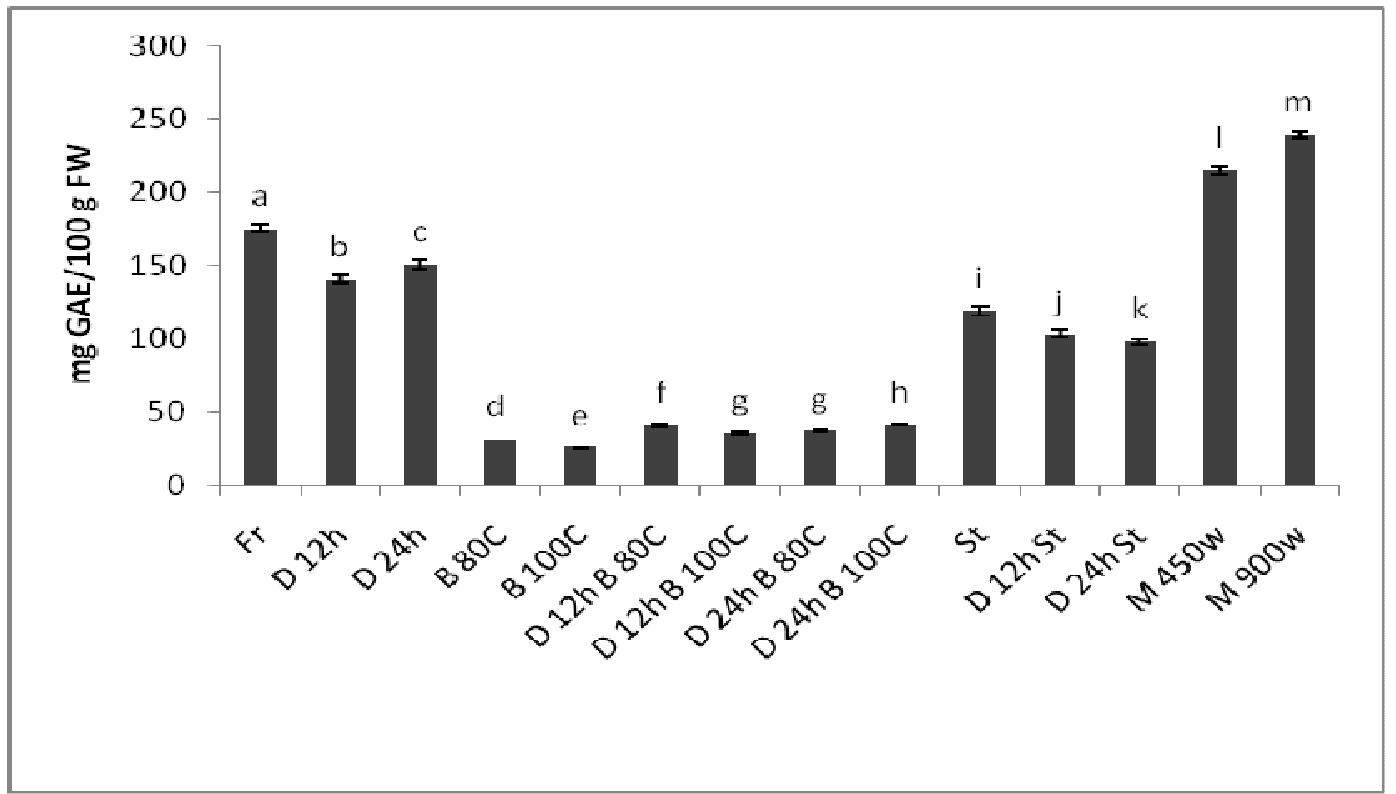

Fig. 1 (B) Total phenolic content of processed H. elongata extract (mg gallic acid

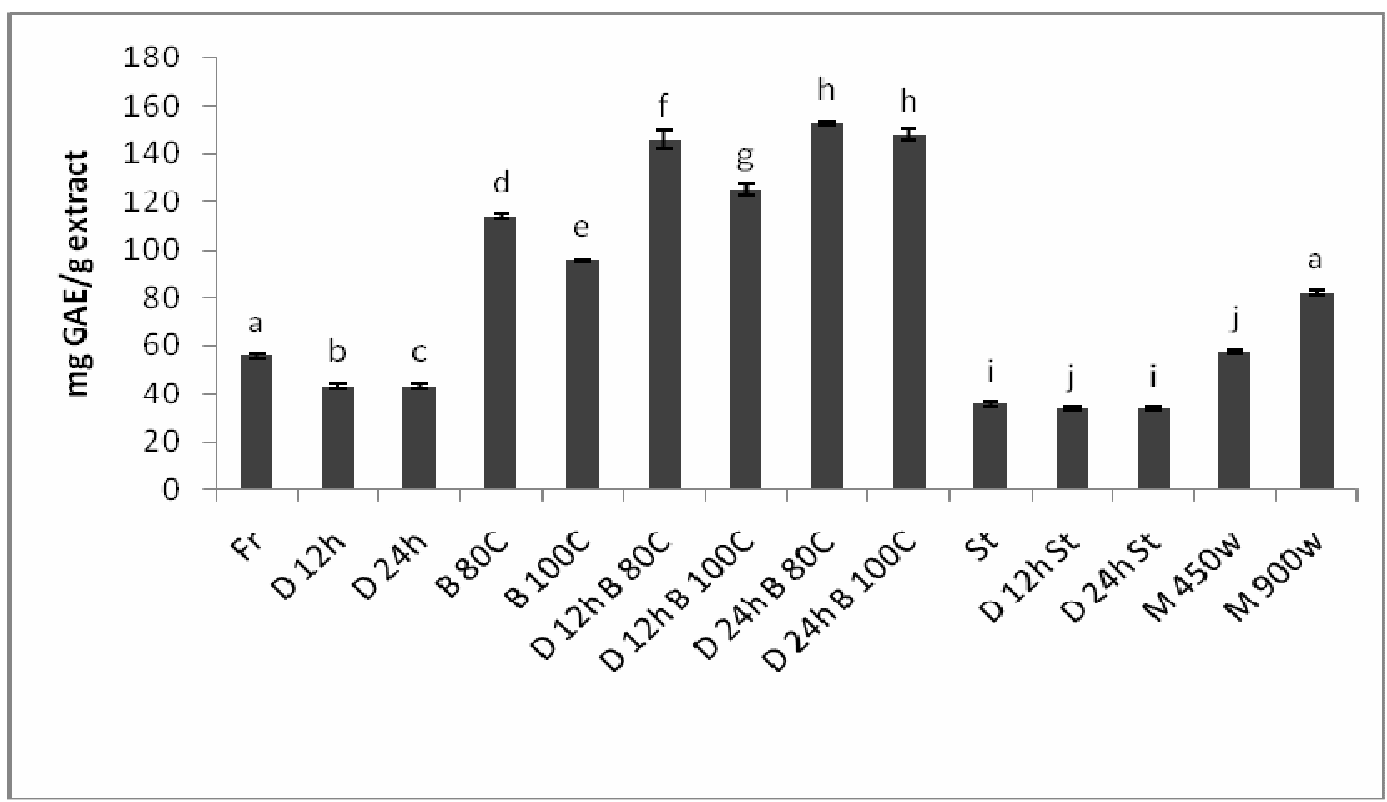

815 Each value is presented as mean $\pm \operatorname{SD}(n=6)$.

816 Means above each bar with different letters $(\mathrm{a}-\mathrm{j})$ differ significantly $(p<0.05)$

817 Where each abbreviation is as follows. Fr: fresh; D 12h: Dried 12 hours; D 24h: Dried 24 hours; B 80C: Boiled $80^{\circ} \mathrm{C}$; B 100C: Boiled $100^{\circ} \mathrm{C}$; D 12h B 80C: Dried 12 hours and Boiled $80^{\circ} \mathrm{C}$; D $12 \mathrm{~h} \mathrm{~B} \mathrm{100C:} \mathrm{Dried} 12$ hours and Boiled $100^{\circ} \mathrm{C}$; D 24h B 80C: Dried 24 hours and Boiled $80^{\circ} \mathrm{C}$; D 24h B 100C: Dried 24 hours and Boiled $100^{\circ} \mathrm{C}$; St: Steamed; D 12h St: Dried 12 hours and Steamed; D 24h St: Dried 24 hours and Steamed; M 450w: Microwaved at 450 Watts; M 900w: Microwaved at 900 Watts. 

radical scavenging activity $(\%)$ of processed $H$. elongata extracts (concentration 100 $\mu \mathrm{g} / \mathrm{ml})$ and $\mathrm{EC}_{50}(\mu \mathrm{g} / \mathrm{ml}) *$ of each extract

\begin{tabular}{|c|c|c|c|}
\hline Processing treatment & $\begin{array}{l}\text { Total } \\
\text { methanol } \\
\text { extract }(\%)\end{array}$ & $\begin{array}{l}\text { DPPH radical } \\
\text { scavenging activity } \\
(\%)\end{array}$ & $\mathrm{EC}_{50}(\mu \mathrm{g} / \mathrm{ml})$ \\
\hline Fresh & $3.14 \pm 0.19^{\mathrm{a}}$ & $75.50 \pm 2.30^{\mathrm{a}}$ & $25.00 \pm 1.81^{\mathrm{a}}$ \\
\hline Dried $12 \mathrm{~h}$ & $3.25 \pm 0.20^{\mathrm{a}}$ & $74.69 \pm 2.31^{\mathrm{b}}$ & $50.00 \pm 3.31^{\mathrm{b}}$ \\
\hline Dried $24 \mathrm{~h}$ & $3.48 \pm 0.29^{\mathrm{ab}}$ & $67.87 \pm 1.05^{\mathrm{c}}$ & $50.00 \pm 2.55^{\mathrm{b}}$ \\
\hline Boiled $80^{\circ} \mathrm{C}-40 \mathrm{~min}$ & $0.27 \pm 0.09^{c}$ & $92.96 \pm 1.55^{\mathrm{d}}$ & $12.50 \pm 1.12^{\mathrm{c}}$ \\
\hline Boiled $100^{\circ} \mathrm{C}-35 \mathrm{~min}$ & $0.26 \pm 0.06^{\mathrm{c}}$ & $93.54 \pm 1.24^{\mathrm{e}}$ & $12.50 \pm 2.00^{\mathrm{c}}$ \\
\hline $\begin{array}{l}\text { Dried } 12 \mathrm{~h} \text { and boiled } 80^{\circ} \mathrm{C}-30 \\
\text { min }\end{array}$ & $0.28 \pm 0.05^{\mathrm{c}}$ & $95.33 \pm 0.80^{f}$ & $12.50 \pm 1.00^{\mathrm{c}}$ \\
\hline $\begin{array}{l}\text { Dried } 12 \mathrm{~h} \text { and boiled } 100^{\circ} \mathrm{C}- \\
25 \mathrm{~min}\end{array}$ & $0.28 \pm 0.06^{\mathrm{c}}$ & $100.00 \pm 0.00^{\mathrm{g}}$ & $12.50 \pm 1.02^{\mathrm{c}}$ \\
\hline $\begin{array}{l}\text { Dried } 24 \mathrm{~h} \text { and boiled } 80^{\circ} \mathrm{C}-30 \\
\text { min }\end{array}$ & $0.24 \pm 0.02^{\mathrm{c}}$ & $88.50 \pm 1.24^{h}$ & $12.50 \pm 1.21^{\mathrm{c}}$ \\
\hline $\begin{array}{l}\text { Dried } 24 \mathrm{~h} \text { and boiled } 100^{\circ} \mathrm{C}- \\
20 \mathrm{~min}\end{array}$ & $0.27 \pm 0.02^{\mathrm{c}}$ & $89.04 \pm 1.85^{\mathrm{i}}$ & $12.50 \pm 1.00^{\mathrm{c}}$ \\
\hline Steamed - $45 \mathrm{~min}$ & $3.37 \pm 0.21^{\mathrm{a}}$ & $52.51 \pm 0.56^{j}$ & $100.00 \pm 0.98^{d}$ \\
\hline Dried $12 \mathrm{~h}$ and steamed $-50 \mathrm{~min}$ & $3.31 \pm 0.19^{\mathrm{a}}$ & $53.79 \pm 1.88^{\mathrm{k}}$ & $100.00 \pm 1.99^{\mathrm{d}}$ \\
\hline Dried $24 \mathrm{~h}$ and steamed $-50 \mathrm{~min}$ & $3.30 \pm 0.20^{\mathrm{a}}$ & $53.50 \pm 0.97^{1}$ & $100.00 \pm 0.96^{\mathrm{d}}$ \\
\hline Microwaved 450w - $30 \mathrm{~s}$ & $3.75 \pm 0.55^{\mathrm{b}}$ & $76.29 \pm 1.57^{\mathrm{m}}$ & $25.00 \pm 1.52^{\mathrm{a}}$ \\
\hline Microwaved $900 w-20 s$ & $4.34 \pm 0.56^{\mathrm{d}}$ & $75.35 \pm 2.00^{\mathrm{n}}$ & $25.00 \pm 1.88^{\mathrm{a}}$ \\
\hline
\end{tabular}

830 


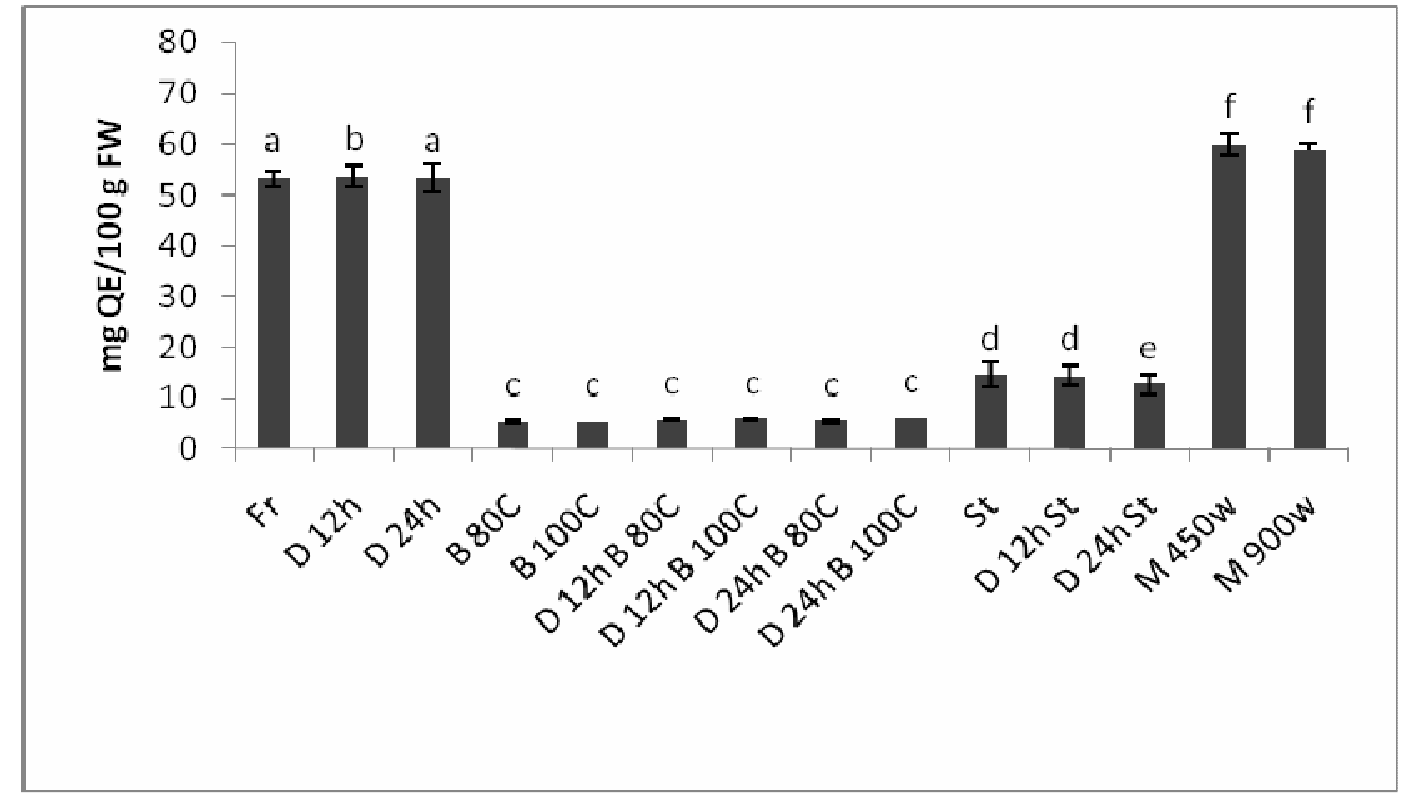

Each value is presented as mean $\pm \operatorname{SD}(n=6)$.

Fig. 2 (B) Total flavanoid content of processed $H$. elongata extract (mg quercetin equivalents/g extract)

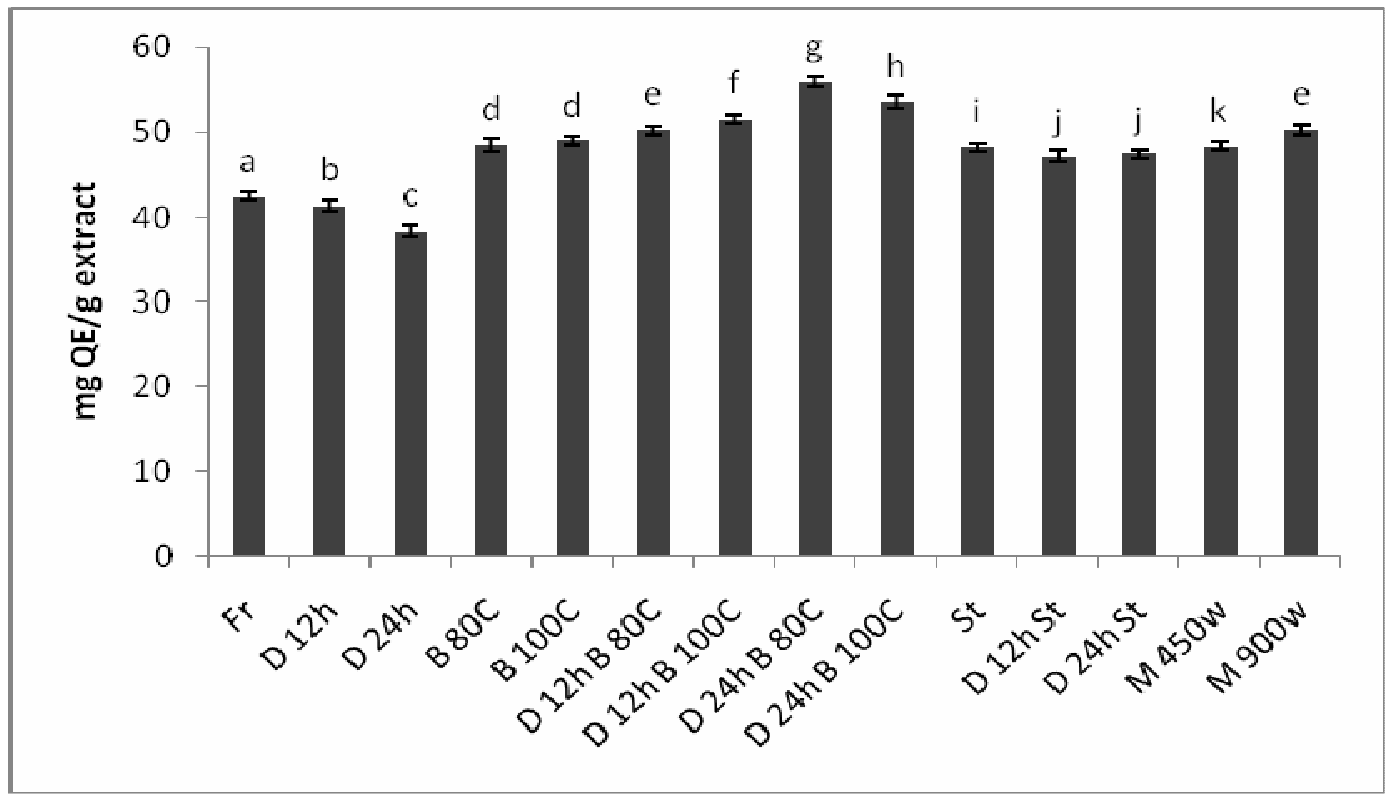

Each value is presented as mean $\pm \operatorname{SD}(n=6)$.

Where each abbreviation is as follows. Fr: fresh; D 12h: Dried 12 hours; D 24h: Dried 24 hours; B 80C: Boiled

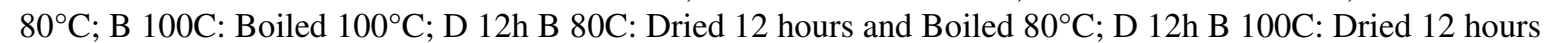
and Boiled $100^{\circ} \mathrm{C}$; D 24h B 80C: Dried 24 hours and Boiled $80^{\circ} \mathrm{C}$; D 24h B 100C: Dried 24 hours and Boiled $100^{\circ} \mathrm{C}$; St: Steamed; D 12h St: Dried 12 hours and Steamed; D 24h St: Dried 24 hours and Steamed; M 450w: 


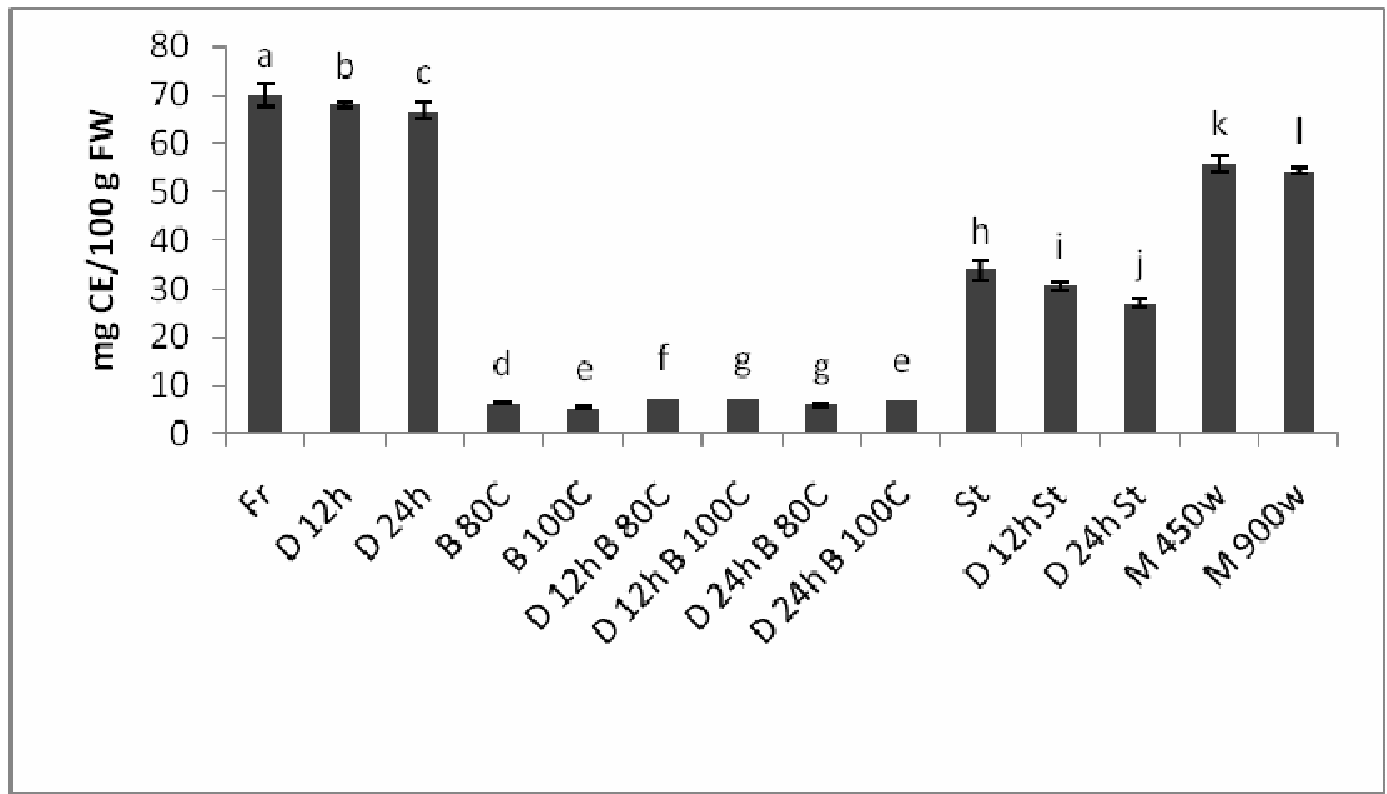

Each value is presented as mean $\pm S D(n=6)$. equivalents/g extract)

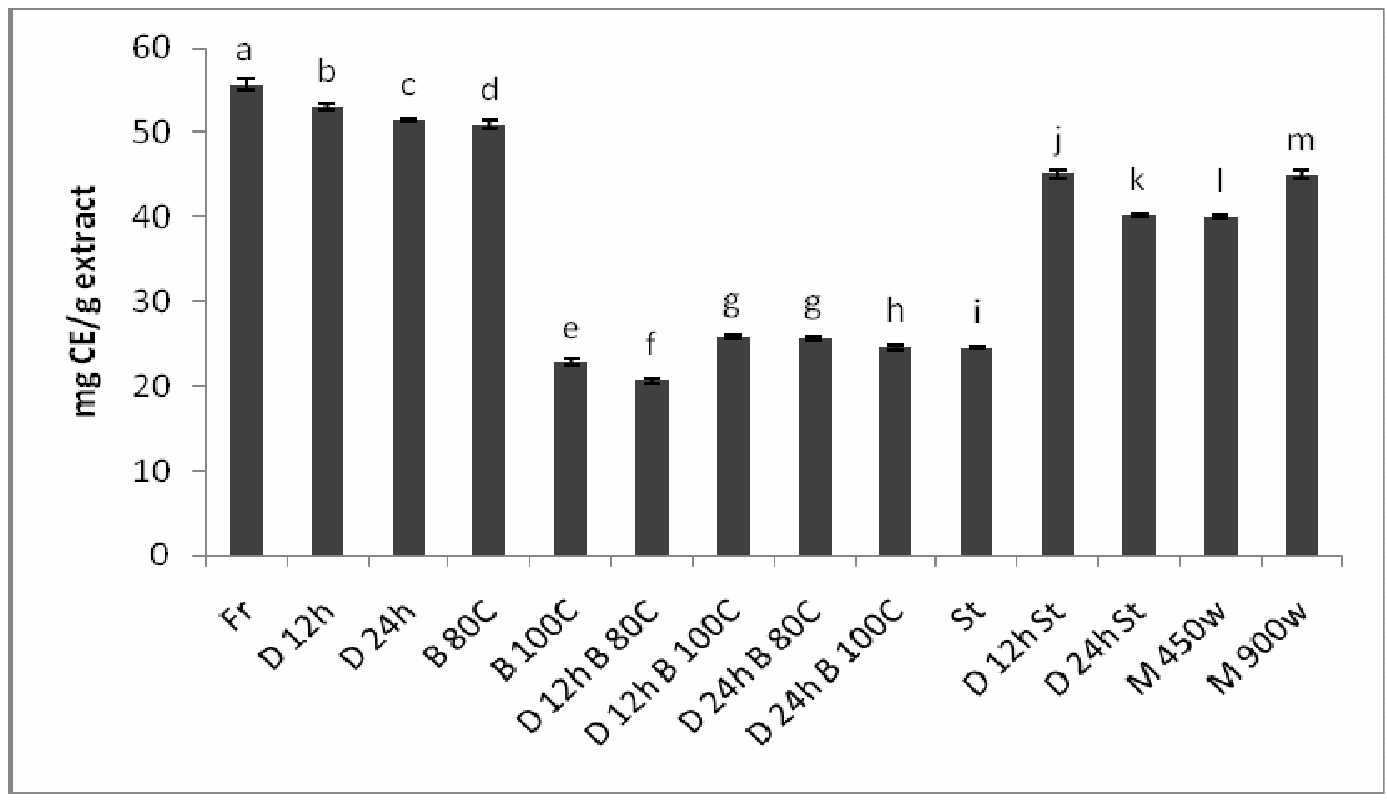

Each value is presented as mean $\pm \operatorname{SD}(n=6)$.

\section{Means above each bar with different letters (a-n) differ significantly $(p<0.05)$}

Where each abbreviation is as follows. Fr: fresh; D 12h: Dried 12 hours; D 24h: Dried 24 hours; B 80C: Boiled $80^{\circ} \mathrm{C}$; B 100C: Boiled $100^{\circ} \mathrm{C}$; D 12h B 80C: Dried 12 hours and Boiled $80^{\circ} \mathrm{C}$; D 12h B 100C: Dried 12 hours and Boiled $100^{\circ} \mathrm{C}$; D 24h B 80C: Dried 24 hours and Boiled $80^{\circ} \mathrm{C}$; D 24h B 100C: Dried 24 hours and Boiled $100^{\circ} \mathrm{C}$; St: Steamed; D 12h St: Dried 12 hours and Steamed; D 24h St: Dried 24 hours and Steamed; M 450w: Microwaved at 450 Watts; M 900w: Microwaved at 900 Watts. 
Table 3. Concentration of $\boldsymbol{H}$. elongata extracts $(\mathrm{mg} / \mathrm{ml})$ from different processed seaweeds ( $5 \mathrm{~g}$ original seaweed) for each dilution tested

\begin{tabular}{|c|c|c|c|c|}
\hline $\begin{array}{l}\text { Processing } \\
\text { treatment }\end{array}$ & $\begin{array}{l}\begin{array}{l}\text { Dilution } 1 \\
(\mathrm{mg} / \mathrm{ml})\end{array} \\
\end{array}$ & $\begin{array}{l}\begin{array}{l}\text { Dilution } 2 \\
(\mathrm{mg} / \mathrm{ml})\end{array} \\
\end{array}$ & $\begin{array}{l}\begin{array}{l}\text { Dilution } 3 \\
(\mathrm{mg} / \mathrm{ml})\end{array} \\
\end{array}$ & $\begin{array}{l}\begin{array}{l}\text { Dilution } 4 \\
(\mathrm{mg} / \mathrm{ml})\end{array} \\
\end{array}$ \\
\hline Fresh & 31.44 & 15.72 & 7.86 & 3.93 \\
\hline Dried $12 \mathrm{~h}$ & 32.47 & 16.23 & 8.12 & 4.06 \\
\hline Dried $24 \mathrm{~h}$ & 34.77 & 17.39 & 8.69 & 4.35 \\
\hline Boiled $80^{\circ} \mathrm{C}-40 \mathrm{~min}$ & 2.73 & 1.36 & 0.68 & 0.34 \\
\hline $\begin{array}{l}\text { Boiled } 100^{\circ} \mathrm{C}-35 \\
\text { min }\end{array}$ & 2.67 & 1.33 & 0.67 & 0.33 \\
\hline $\begin{array}{l}\text { Dried } 12 \mathrm{~h} \text { and boiled } \\
80^{\circ} \mathrm{C}-30 \mathrm{~min}\end{array}$ & 2.80 & 1.40 & 0.70 & 0.35 \\
\hline $\begin{array}{l}\text { Dried } 12 \mathrm{~h} \text { and boiled } \\
100^{\circ} \mathrm{C}-25 \mathrm{~min}\end{array}$ & 2.82 & 1.41 & 0.70 & 0.35 \\
\hline $\begin{array}{l}\text { Dried } 24 \mathrm{~h} \text { and boiled } \\
80^{\circ} \mathrm{C}-30 \mathrm{~min}\end{array}$ & 2.42 & 1.21 & 0.61 & 0.30 \\
\hline $\begin{array}{l}\text { Dried } 24 \mathrm{~h} \text { and boiled } \\
100^{\circ} \mathrm{C}-20 \mathrm{~min}\end{array}$ & 2.77 & 1.38 & 0.69 & 0.35 \\
\hline Steamed - $45 \mathrm{~min}$ & 34.00 & 17.00 & 8.50 & 4.25 \\
\hline $\begin{array}{l}\text { Dried } 12 \mathrm{~h} \text { and } \\
\text { steamed }-50 \mathrm{~min}\end{array}$ & 31.00 & 15.50 & 7.75 & 3.88 \\
\hline $\begin{array}{l}\text { Dried } 24 \mathrm{~h} \text { and } \\
\text { steamed }-50 \text { min }\end{array}$ & 29.30 & 14.65 & 7.33 & 3.66 \\
\hline $\begin{array}{l}\text { Microwaved 450w - } \\
30 \mathrm{~s}\end{array}$ & 37.56 & 18.78 & 9.39 & 4.69 \\
\hline $\begin{array}{l}\text { Microwaved 900w - } \\
20 \mathrm{~s}\end{array}$ & 43.47 & 21.74 & 10.87 & 5.43 \\
\hline
\end{tabular}


905

906

907

Table 4. Percentage inhibition of methanolic extracts of $\boldsymbol{H}$. elongata processed under different conditions against $L$. monocytogenes

\begin{tabular}{|c|c|c|c|c|}
\hline $\begin{array}{l}\text { Processing } \\
\text { treatment }\end{array}$ & Dilution 1 & Dilution 2 & Dilution 3 & Dilution 4 \\
\hline Fresh & $100.00 \pm 0.0^{\mathrm{aw}}$ & $100.00 \pm 0.00^{\mathrm{aw}}$ & $99.37 \pm 1.24^{\mathrm{ax}}$ & $98.09 \pm 3.81^{\text {ay }}$ \\
\hline Dried $12 \mathrm{~h}$ & $100.00 \pm 0.0^{\mathrm{aw}}$ & $89.88 \pm 1.70^{\mathrm{bx}}$ & $43.89 \pm 1.43^{\text {by }}$ & $31.68 \pm 2.08^{\mathrm{bz}}$ \\
\hline Dried $24 \mathrm{~h}$ & $100.00 \pm 0.0^{\mathrm{aw}}$ & $92.99 \pm 8.16^{\mathrm{cx}}$ & $29.84 \pm 2.19^{\text {cy }}$ & $26.98 \pm 6.72^{\mathrm{cz}}$ \\
\hline Boiled $80^{\circ} \mathrm{C}-40 \mathrm{~min}$ & $27.05 \pm 0.60^{\mathrm{bw}}$ & $0.00 \pm 0.00^{\mathrm{dx}}$ & $0.00 \pm 0.00^{\mathrm{dx}}$ & $0.00 \pm 0.00^{\mathrm{dx}}$ \\
\hline $\begin{array}{l}\text { Boiled } 100^{\circ} \mathrm{C}-35 \\
\text { min }\end{array}$ & $46.45 \pm 3.42^{\mathrm{cw}}$ & $0.00 \pm 0.00^{\mathrm{dx}}$ & $0.00 \pm 0.00^{\mathrm{dx}}$ & $0.00 \pm 0.00^{\mathrm{dx}}$ \\
\hline $\begin{array}{l}\text { Dried } 12 \mathrm{~h} \text { and boiled } \\
80^{\circ} \mathrm{C}-30 \mathrm{~min}\end{array}$ & $24.95 \pm 3.51^{\mathrm{dw}}$ & $10.00 \pm 1.71^{\mathrm{ex}}$ & $0.00 \pm 0.00^{\mathrm{dy}}$ & $0.00 \pm 0.00^{\mathrm{dy}}$ \\
\hline $\begin{array}{l}\text { Dried } 12 \mathrm{~h} \text { and boiled } \\
100^{\circ} \mathrm{C}-25 \mathrm{~min}\end{array}$ & $21.02 \pm 2.54^{\mathrm{ew}}$ & $14.00 \pm 0.25^{\mathrm{fx}}$ & $0.00 \pm 0.00^{\mathrm{dy}}$ & $0.00 \pm 0.00^{\mathrm{dy}}$ \\
\hline $\begin{array}{l}\text { Dried } 24 \mathrm{~h} \text { and boiled } \\
80^{\circ} \mathrm{C}-30 \mathrm{~min}\end{array}$ & $10.48 \pm 3.23^{\mathrm{fw}}$ & $9.81 \pm 1.15^{\mathrm{gx}}$ & $0.00 \pm 0.00^{\mathrm{dy}}$ & $0.00 \pm 0.00^{\mathrm{dy}}$ \\
\hline $\begin{array}{l}\text { Dried } 24 \mathrm{~h} \text { and boiled } \\
100^{\circ} \mathrm{C}-20 \mathrm{~min}\end{array}$ & $23.20 \pm 2.54^{\mathrm{gw}}$ & $15.89 \pm 1.68^{\mathrm{hx}}$ & $0.00 \pm 0.00^{\mathrm{dy}}$ & $0.00 \pm 0.00^{\mathrm{dy}}$ \\
\hline Steamed - $45 \mathrm{~min}$ & $96.34 \pm 3.64^{\mathrm{hw}}$ & $96.24 \pm 1.56^{\mathrm{ix}}$ & $81.54 \pm 5.56^{\mathrm{ey}}$ & $77.88 \pm 5.54^{\mathrm{ez}}$ \\
\hline $\begin{array}{l}\text { Dried } 12 \mathrm{~h} \text { and } \\
\text { steamed }-50 \mathrm{~min}\end{array}$ & $43.25 \pm 3.23^{\mathrm{iw}}$ & $35.14 \pm 0.25^{\mathrm{jx}}$ & $29.57 \pm 1.77^{\text {fy }}$ & $20.45 \pm 0.78^{\mathrm{fz}}$ \\
\hline $\begin{array}{l}\text { Dried } 24 \mathrm{~h} \text { and } \\
\text { steamed }-50 \mathrm{~min}\end{array}$ & $43.85 \pm 0.23^{\mathrm{jw}}$ & $34.15 \pm 1.12^{\mathrm{kx}}$ & $28.89 \pm 1.89^{\mathrm{gy}}$ & $19.55 \pm 0.98^{\mathrm{gz}}$ \\
\hline $\begin{array}{l}\text { Microwaved 450w - } \\
30 \mathrm{~s}\end{array}$ & $97.24 \pm 0.05^{\mathrm{kw}}$ & $82.90 \pm 5.90^{1 x}$ & $48.73 \pm 1.57^{\text {hy }}$ & $29.41 \pm 5.45^{\mathrm{hz}}$ \\
\hline $\begin{array}{l}\text { Microwaved 900w - } \\
20 \mathrm{~s}\end{array}$ & $97.26 \pm 1.25^{\mathrm{ew}}$ & $81.45 \pm 3.07^{\mathrm{mx}}$ & $74.20 \pm 1.84^{\mathrm{iy}}$ & $72.86 \pm 3.10^{\mathrm{iz}}$ \\
\hline \multicolumn{5}{|c|}{ Each value is presented as mean $\pm S D(n=6)$} \\
\hline
\end{tabular}


Table 5. Percentage inhibition of methanolic extracts of $\boldsymbol{H}$. elongata processed under different conditions against $S$. abony

931

\begin{tabular}{|c|c|c|c|c|}
\hline $\begin{array}{l}\text { Processing } \\
\text { treatment }\end{array}$ & Dilution 1 & Dilution 2 & Dilution 3 & Dilution 4 \\
\hline Fresh & $87.03 \pm 3.91^{\mathrm{aw}}$ & $78.80 \pm 1.41^{\mathrm{ax}}$ & $65.13 \pm 4.60^{\mathrm{ay}}$ & $37.18 \pm 5.71^{\mathrm{az}}$ \\
\hline Dried $12 \mathrm{~h}$ & $77.29 \pm 1.26^{\mathrm{bw}}$ & $39.24 \pm 2.27^{\mathrm{bx}}$ & $26.83 \pm 3.75^{\text {by }}$ & $11.01 \pm 2.06^{\mathrm{bz}}$ \\
\hline Dried $24 \mathrm{~h}$ & $83.52 \pm 4.23^{\mathrm{cw}}$ & $49.01 \pm 3.08^{\mathrm{cx}}$ & $27.17 \pm 4.02^{\mathrm{cy}}$ & $10.99 \pm 1.07^{\mathrm{cz}}$ \\
\hline Boiled $80^{\circ} \mathrm{C}-40 \mathrm{~min}$ & $10.37 \pm 3.97^{\mathrm{dw}}$ & $5.50 \pm 0.12^{\mathrm{dx}}$ & $0.00 \pm 0.00^{\mathrm{dy}}$ & $0.00 \pm 0.00^{\mathrm{dy}}$ \\
\hline $\begin{array}{l}\text { Boiled } 100^{\circ} \mathrm{C}-35 \\
\text { min }\end{array}$ & $16.56 \pm 4.11^{\mathrm{ew}}$ & $0.00 \pm 0.00^{\mathrm{ex}}$ & $0.00 \pm 0.00^{\mathrm{dx}}$ & $0.00 \pm 0.00^{\mathrm{dx}}$ \\
\hline $\begin{array}{l}\text { Dried } 12 \mathrm{~h} \text { and boiled } \\
80^{\circ} \mathrm{C}-30 \mathrm{~min}\end{array}$ & $13.73 \pm 1.09^{\mathrm{fw}}$ & $10.34 \pm 0.89^{\mathrm{fx}}$ & $0.00 \pm 0.00^{\mathrm{dy}}$ & $0.00 \pm 0.00^{\mathrm{dy}}$ \\
\hline $\begin{array}{l}\text { Dried } 12 \mathrm{~h} \text { and boiled } \\
100^{\circ} \mathrm{C}-25 \mathrm{~min}\end{array}$ & $13.87 \pm 1.69^{\mathrm{gw}}$ & $6.01 \pm 1.29^{\mathrm{gx}}$ & $0.00 \pm 0.00^{\mathrm{dy}}$ & $0.00 \pm 0.00^{\mathrm{dy}}$ \\
\hline $\begin{array}{l}\text { Dried } 24 \mathrm{~h} \text { and boiled } \\
80^{\circ} \mathrm{C}-30 \mathrm{~min}\end{array}$ & $22.11 \pm 2.98^{\mathrm{hw}}$ & $10.61 \pm 1.68^{\mathrm{gx}}$ & $0.00 \pm 0.00^{\mathrm{dy}}$ & $0.00 \pm 0.00^{\mathrm{dy}}$ \\
\hline $\begin{array}{l}\text { Dried } 24 \mathrm{~h} \text { and boiled } \\
100^{\circ} \mathrm{C}-20 \mathrm{~min}\end{array}$ & $15.54 \pm 1.75^{\mathrm{iw}}$ & $11.02 \pm 4.87^{\mathrm{hx}}$ & $0.00 \pm 0.00^{\mathrm{dy}}$ & $0.00 \pm 0.00^{\mathrm{dy}}$ \\
\hline Steamed - $45 \min$ & $93.23 \pm 2.51^{\mathrm{jw}}$ & $93.04 \pm 2.51^{\mathrm{ix}}$ & $82.45 \pm 4.25^{\mathrm{ey}}$ & $77.12 \pm 4.45^{\mathrm{ez}}$ \\
\hline $\begin{array}{l}\text { Dried } 12 \mathrm{~h} \text { and } \\
\text { steamed }-50 \mathrm{~min}\end{array}$ & $44.21 \pm 3.78^{\mathrm{kw}}$ & $35.78 \pm 0.29^{\mathrm{jx}}$ & $29.87 \pm 2.51^{\text {fy }}$ & $20.12 \pm 2.58^{\mathrm{fz}}$ \\
\hline $\begin{array}{l}\text { Dried } 24 \mathrm{~h} \text { and } \\
\text { steamed - } 50 \mathrm{~min}\end{array}$ & $44.12 \pm 2.53^{\mathrm{kw}}$ & $36.15 \pm 1.25^{\mathrm{kx}}$ & $28.78 \pm 1.88^{\mathrm{gy}}$ & $19.70 \pm 1.80^{\mathrm{gz}}$ \\
\hline $\begin{array}{l}\text { Microwaved 450w - } \\
30 \mathrm{~s}\end{array}$ & $93.00 \pm 0.98^{1 \mathrm{w}}$ & $58.65 \pm 1.29^{1 \mathrm{x}}$ & $48.62 \pm 1.58^{\text {hy }}$ & $30.64 \pm 1.35^{\mathrm{hz}}$ \\
\hline $\begin{array}{l}\text { Microwaved 900w - } \\
20 \mathrm{~s}\end{array}$ & $94.40 \pm 1.58^{\mathrm{mw}}$ & $64.09 \pm 2.26^{\mathrm{mx}}$ & $53.07 \pm 5.98^{\mathrm{iy}}$ & $31.28 \pm 3.78^{\mathrm{iz}}$ \\
\hline
\end{tabular}

935

936

937

938

939

940

941

942

943

944 
Table 6. Percentage inhibition of methanolic extracts of $\boldsymbol{H}$. elongata processed under

\section{different conditions against $E$. faecalis}

\begin{tabular}{|c|c|c|c|c|}
\hline $\begin{array}{l}\text { Processing } \\
\text { treatment }\end{array}$ & Dilution 1 & Dilution 2 & Dilution 3 & Dilution 4 \\
\hline Fresh & $100.00 \pm 0.00^{\mathrm{aw}}$ & $99.61 \pm 0.66^{\mathrm{ax}}$ & $87.03 \pm 1.41^{\text {ay }}$ & $78.02 \pm 0.98^{\mathrm{az}}$ \\
\hline Dried $12 \mathrm{~h}$ & $100.00 \pm 0.00^{\mathrm{aw}}$ & $39.24 \pm 2.27^{\mathrm{bx}}$ & $36.30 \pm 6.50^{\text {by }}$ & $33.89 \pm 5.10^{\mathrm{bz}}$ \\
\hline Dried $24 \mathrm{~h}$ & $95.40 \pm 0.72^{\mathrm{bw}}$ & $53.01 \pm 3.08^{\mathrm{cx}}$ & $42.28 \pm 0.08^{\mathrm{cy}}$ & $29.96 \pm 1.38^{\mathrm{cz}}$ \\
\hline Boiled $80^{\circ} \mathrm{C}-40 \mathrm{~min}$ & $7.31 \pm 1.25^{\mathrm{cw}}$ & $5.50 \pm 0.12^{\mathrm{dx}}$ & $0.00 \pm 0.00^{\mathrm{dy}}$ & $0.00 \pm 0.00^{\mathrm{dy}}$ \\
\hline $\begin{array}{l}\text { Boiled } 100^{\circ} \mathrm{C}-35 \\
\text { min }\end{array}$ & $10.52 \pm 2.54^{\mathrm{dw}}$ & $0.00 \pm 0.00^{\mathrm{ex}}$ & $0.00 \pm 0.00^{\mathrm{dx}}$ & $0.00 \pm 0.00^{\mathrm{dx}}$ \\
\hline $\begin{array}{l}\text { Dried } 12 \mathrm{~h} \text { and boiled } \\
80^{\circ} \mathrm{C}-30 \mathrm{~min}\end{array}$ & $49.45 \pm 1.26^{\mathrm{ew}}$ & $10.34 \pm 0.89^{f x}$ & $0.00 \pm 0.00^{\mathrm{dy}}$ & $0.00 \pm 0.00^{\mathrm{dy}}$ \\
\hline $\begin{array}{l}\text { Dried } 12 \mathrm{~h} \text { and boiled } \\
100^{\circ} \mathrm{C}-25 \mathrm{~min}\end{array}$ & $22.11 \pm 4.32^{\mathrm{fw}}$ & $6.01 \pm 1.29^{\mathrm{dx}}$ & $0.00 \pm 0.00^{\mathrm{dy}}$ & $0.00 \pm 0.00^{\mathrm{dy}}$ \\
\hline $\begin{array}{l}\text { Dried } 24 \mathrm{~h} \text { and boiled } \\
80^{\circ} \mathrm{C}-30 \mathrm{~min}\end{array}$ & $16.67 \pm 2.46^{\mathrm{gw}}$ & $10.61 \pm 1.68^{\mathrm{gx}}$ & $0.00 \pm 0.00^{\mathrm{dy}}$ & $0.00 \pm 0.00^{\mathrm{dy}}$ \\
\hline $\begin{array}{l}\text { Dried } 24 \mathrm{~h} \text { and boiled } \\
100^{\circ} \mathrm{C}-20 \mathrm{~min}\end{array}$ & $33.72 \pm 3.92^{\mathrm{hw}}$ & $11.02 \pm 4.87^{\mathrm{gx}}$ & $0.00 \pm 0.00^{\mathrm{dy}}$ & $0.00 \pm 0.00^{\mathrm{dy}}$ \\
\hline Steamed - $45 \mathrm{~min}$ & $95.21 \pm 1.29^{\mathrm{iw}}$ & $93.54 \pm 2.51^{\mathrm{hx}}$ & $81.47 \pm 1.58^{\mathrm{ey}}$ & $76.42 \pm 2.57^{\mathrm{ez}}$ \\
\hline $\begin{array}{l}\text { Dried } 12 \mathrm{~h} \text { and } \\
\text { steamed }-50 \mathrm{~min}\end{array}$ & $42.32 \pm 5.29^{\mathrm{jw}}$ & $35.78 \pm 0.29^{\mathrm{ix}}$ & $28.74 \pm 2.50^{\mathrm{fy}}$ & $19.99 \pm 1.54^{\mathrm{fz}}$ \\
\hline $\begin{array}{l}\text { Dried } 24 \mathrm{~h} \text { and } \\
\text { steamed }-50 \mathrm{~min}\end{array}$ & $44.57 \pm 0.98^{\mathrm{kw}}$ & $36.15 \pm 1.25^{\mathrm{jx}}$ & $29.87 \pm 1.75^{\mathrm{gy}}$ & $18.78 \pm 1.24^{\mathrm{gz}}$ \\
\hline $\begin{array}{l}\text { Microwaved 450w - } \\
30 \mathrm{~s}\end{array}$ & $90.12 \pm 2.54^{1 \mathrm{w}}$ & $48.62 \pm 1.29^{\mathrm{kx}}$ & $31.13 \pm 2.01^{\text {hy }}$ & $23.48 \pm 2.06^{\mathrm{hz}}$ \\
\hline $\begin{array}{l}\text { Microwaved 900w - } \\
20 \mathrm{~s}\end{array}$ & $95.81 \pm 4.58^{\mathrm{mw}}$ & $53.07 \pm 2.26^{\mathrm{cx}}$ & $43.61 \pm 3.39^{\mathrm{iy}}$ & $24.42 \pm 5.14^{\mathrm{iz}}$ \\
\hline
\end{tabular}


Table 7. Percentage inhibition of methanolic extracts of $\boldsymbol{H}$. elongata processed under

\section{different conditions against $P$. aeruginosa}

\begin{tabular}{|c|c|c|c|c|}
\hline $\begin{array}{l}\text { Processing } \\
\text { treatment }\end{array}$ & Dilution 1 & Dilution 2 & Dilution 3 & Dilution 4 \\
\hline Fresh & $96.39 \pm 2.55^{\mathrm{aw}}$ & $89.11 \pm 3.31^{\mathrm{ax}}$ & $74.63 \pm 6.64^{\text {ay }}$ & $51.11 \pm 5.84^{\mathrm{az}}$ \\
\hline Dried $12 \mathrm{~h}$ & $72.80 \pm 5.22^{\mathrm{bw}}$ & $48.77 \pm 5.26^{\mathrm{bx}}$ & $17.71 \pm 3.02^{\text {by }}$ & $1.93 \pm 0.72^{\mathrm{bz}}$ \\
\hline Dried $24 \mathrm{~h}$ & $94.05 \pm 4.03^{\mathrm{cw}}$ & $41.19 \pm 5.8^{\mathrm{cx}}$ & $22.88 \pm 7.57^{\mathrm{cy}}$ & $12.16 \pm 0.18^{\mathrm{cz}}$ \\
\hline Boiled $80^{\circ} \mathrm{C}-40 \mathrm{~min}$ & $6.45 \pm 2.00^{\mathrm{dw}}$ & $5.46 \pm 1.23^{\mathrm{dx}}$ & $0.00 \pm 0.00^{\mathrm{dy}}$ & $0.00 \pm 0.00^{\mathrm{dy}}$ \\
\hline $\begin{array}{l}\text { Boiled } 100^{\circ} \mathrm{C}-35 \\
\text { min }\end{array}$ & $34.74 \pm 1.52^{\mathrm{ew}}$ & $5.03 \pm 5.27^{\mathrm{ex}}$ & $0.00 \pm 0.00^{\mathrm{dy}}$ & $0.00 \pm 0.00^{\mathrm{dy}}$ \\
\hline $\begin{array}{l}\text { Dried } 12 \mathrm{~h} \text { and boiled } \\
80^{\circ} \mathrm{C}-30 \text { min }\end{array}$ & $22.94 \pm 2.34^{\mathrm{fw}}$ & $22.92 \pm 1.56^{\mathrm{fx}}$ & $0.00 \pm 0.00^{\mathrm{dy}}$ & $0.00 \pm 0.00^{\mathrm{dy}}$ \\
\hline $\begin{array}{l}\text { Dried } 12 \mathrm{~h} \text { and boiled } \\
100^{\circ} \mathrm{C}-25 \mathrm{~min}\end{array}$ & $23.09 \pm 1.20^{\mathrm{gw}}$ & $12.19 \pm 1.15^{\mathrm{gx}}$ & $0.00 \pm 0.00^{\mathrm{dy}}$ & $0.00 \pm 0.00^{\mathrm{dy}}$ \\
\hline $\begin{array}{l}\text { Dried } 24 \mathrm{~h} \text { and boiled } \\
80^{\circ} \mathrm{C}-30 \mathrm{~min}\end{array}$ & $24.21 \pm 1.60^{\mathrm{hw}}$ & $10.21 \pm 1.07^{\mathrm{hx}}$ & $0.00 \pm 0.00^{\mathrm{dy}}$ & $0.00 \pm 0.00^{\mathrm{dy}}$ \\
\hline $\begin{array}{l}\text { Dried } 24 \mathrm{~h} \text { and boiled } \\
100^{\circ} \mathrm{C}-20 \mathrm{~min}\end{array}$ & $34.12 \pm 3.24^{\mathrm{iw}}$ & $20.98 \pm 3.24^{\mathrm{ix}}$ & $0.00 \pm 0.00^{\mathrm{dy}}$ & $0.00 \pm 0.00^{\mathrm{dy}}$ \\
\hline Steamed - 45 min & $95.32 \pm 2.99^{j w}$ & $85.66 \pm 1.58^{\mathrm{jx}}$ & $83.45 \pm 1.89^{\mathrm{ey}}$ & $77.54 \pm 3.45^{\mathrm{ex}}$ \\
\hline $\begin{array}{l}\text { Dried } 12 \mathrm{~h} \text { and } \\
\text { steamed }-50 \mathrm{~min}\end{array}$ & $44.14 \pm 4.54^{\mathrm{kw}}$ & $34.21 \pm 0.98^{\mathrm{kx}}$ & $27.89 \pm 2.14^{\mathrm{fy}}$ & $19.78 \pm 2.54^{\mathrm{fz}}$ \\
\hline $\begin{array}{l}\text { Dried } 24 \mathrm{~h} \text { and } \\
\text { steamed - } 50 \text { min }\end{array}$ & $43.25 \pm 1.24^{1 \mathrm{w}}$ & $36.47 \pm 0.16^{1 \mathrm{x}}$ & $28.77 \pm 2.12^{\mathrm{gy}}$ & $19.10 \pm 2.88^{\mathrm{gz}}$ \\
\hline $\begin{array}{l}\text { Microwaved 450w - } \\
30 \mathrm{~s}\end{array}$ & $93.44 \pm 5.48^{\mathrm{mw}}$ & $70.25 \pm 7.30^{\mathrm{mx}}$ & $46.73 \pm 3.56^{\text {hy }}$ & $33.16 \pm 2.31^{\mathrm{hz}}$ \\
\hline $\begin{array}{l}\text { Microwaved 900w - } \\
20 \mathrm{~s}\end{array}$ & $95.73 \pm 4.84^{\mathrm{nw}}$ & $70.21 \pm 1.77^{\mathrm{mx}}$ & $46.85 \pm 5.84^{\mathrm{iy}}$ & $37.73 \pm 4.11^{\mathrm{iz}}$ \\
\hline
\end{tabular}

Means within each row with different letters (w-z) differ significantly $(p<0.05)$

984

985

986

987

988

989

990

991

992

993 